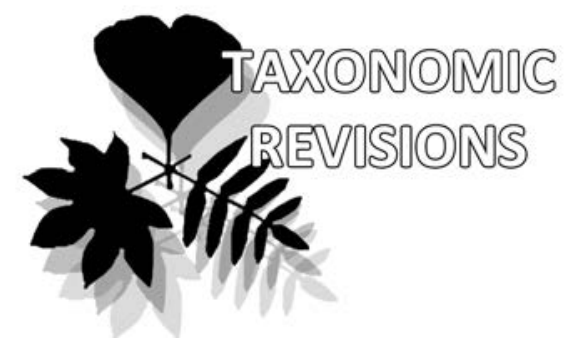

\title{
Liverworts of the Russian Far East: the taxa with ciliate leaves
}

\author{
Vadim A. Bakalin
}

Vadim A. Bakalin

e-mail: vabakalin@gmail.com

Botanical Garden-Institute FEB RAS Vladivostok, Russia

* corresponding author

Manuscript received: 23.10 .2018 Review completed: 28.02.2019 Accepted for publication: 03.03.2019 Published online: 05.03.2019

\begin{abstract}
A B S T R A C T
The liverwort taxa with ciliate leaves occurring in the Russian Far East are reviewed. In total, 9 taxa belonging to four families (Jubulaceae, Ptilidiaceae, Neotrichocoleaceae and Trichocoleaceae) are recorded, 6 species occur in Russia in the Far East only. The identification keys, morphological descriptions and figures based on materials from the Russian Far East are provided.

Ke y w o r d s : Jubulaceae, Ptilidiaceae, Neotrichocoleaceae, Trichocoleaceae, Hepaticae, the Russian Far East, East Asia

\section{P E 3 Ю M E}

Бакалин В.А. Печеночники российского АаАьнего Востока: таксоны с реснитчатыми иистьями. Ревизованы таксоны печеночников с реснитчатыми Аистьями, встречающиеся на российском Аальнем Востоке: 9 видов из 4 семейств (Jubulaceae, Ptilidiaceae, Neotrichocoleaceae and Trichocoleaceae). Шесть вилов встречаются в России только на Аальнем Востоке. Приводятся кАючи Аля опреАеления, морфологические описания и илАюстрации, составленные на основе изучения материала с российского Аальнего Востока. КАючевые слова: Jubulaceae, Ptilidiaceae, Neotrichocoleaceae, Trichocoleaceae, печеночники, российский Аальний Восток, Восточная Азия
\end{abstract}

The liverworts with ciliate leaves occurring in the Russian Far East do not form the monophyletic group; these are representatives of various families belonging to even different orders: Porellales (Jubulaceae), Ptilidiales (Ptilidiaceae, Neotrichocoleaceae) and Jungermanniales (Trichocoleaceae). Plants are also varying in the size, from tiny in Neohattoria herzogii to large in Trichocolea tomentella and Ptilidium ciliare. The attempt to unite all of them in the same treatment is based on practical reason only: the majority of taxa could not be keyed out using keys existed in Russia. Moreover, the keys existed in adjacent countries do not covers all recognized Russian taxa of this group. Therefore the main goal of the present account was to accumulate all available information on liverworts with ciliate leaves known in the Russian Far East and provide descriptions, figures, identification keys and data on ecology and distribution within one paper. The paper treats taxa whose leaf lamina is more or less developed, and does not include such genera as Blepharostoma where leaves divided nearly to the base and no true lamina exists.

\section{TAXONOMIC TREATMENT}

The key to the genera with ciliate leaves and developed leaf lamina occurring in the Russian Far East:

1. Leaves conduplicate or with pyxidate ventral lobe or bear water sac in the base of the leaf

1. Leaves not conduplicate, ventral lobe not pyxidate, no water sac in the leaf base

2. Leaves with water sac in the ventral base ... 3
2. Leaves conduplicate or ventral lobe pyxidate, without water sac in the ventral base of the leaf

3. Cells along leaf margin with large papilla-like protuberances by one per each cell, water sacs present in the base of ventral lobes and underleaves ......Ascidiota blepharophylla [Arctic-Alpine broadly mega-Beringian highly disjunctively distributed taxon, not known in the Russian Far East, but may be found, treated in Bakalin \& Klimova 2019]

3. No papilla like protuberances along leaf margin, underleaves without water sacs, water sac of the leaf is completely transformed ventral lobe

Trichocoleopsis sacculata

4. Leaves with pyxidate ventral lobe 5

4. Leaves with ventral lobe appressed to the dorsal lobe, nearly plane or slightly concave to convex, with 1-4 teeth along upper half

Nipponolejeunea

5. Underleaves only slightly wider than stem (1.2-1.7 of stem width), bilobed, neither ciliate nor dentate, ventral lobes easily caducous, leaves dentate (sometimes prominently so) to shortly ciliate, plants $300-500 \mu \mathrm{m}$ wide

Neobattoria herzogii

5. Underleaves 2-4 times wider than the stem diameter, bitetralobed, commonly with cilia along margin, leaves ciliate, plants commonly wider $1.0 \mathrm{~mm}$ wide ......... Jubula japonica

6. Leaf lamina reduced, the $80 \%$ of the leaf are cilia, plants whitish greenish to brightly so ......... Trichocolea tomentella

6. Leaf lamina not reduced, distinct and relatively wide, triangular lobes divided into several 'sublobes', which terminate by cilia (that may be poorly developed)

Ptilidium 


\section{Jubulaceae H. Klinggr}

Jubulaceae is the small family including three genera (all are known in the Russian Far East), distributed in temperate to tropical (in the latter absent in the low elevations, but common in mountains) amphioceanic areas, southward to northern Australia. They are characterized by green to brownish color of plants without red pigmentation, branching of Lejeunea and Frullania type, rhizoids originating from underleaf bases, incubously inserted leaves with distinct differentiation into dorsal and ventral lobes and dorsal lobe apex acute to piliferous, more or less thin-walled leaf cells, bilobed (sometimes tetralobed) underleaves, absence of perigynium and reduced foot of seta, seta short, capsule bistratose spherical (Frey \& Stech 2009). The status and taxonomical composition of the family remained unclear until recently, when Larraín et al. (2015) clearly defined the structure of the family and its relationships with morphologically similar Frullaniaceae and Lejeuneaceae, especially arguing Neohattoria as the member of Jubulaceae, but not merging with Frullania as it was commonly estimated before. Jubulaceae in the Russian Far East are restricted to southernmost flank of the land and occur in Primorsky Territory, southern flank of Khabarovsk Territory, Sakhalin Island and southern Kurils. The genera were keyed out in the general key.

Jubula Dumort., Commentat. Bot. (Dumortier): 112, 1822

Jubula is the small genus of Hepaticae that counts 5 species (Söderström et al. 2016), although with many subspecies within J. hutchinsiae (Hook.) Dumort. Noticeable all taxa that were tested (Larraín et al. 2015) were placed into subspecies of the last mentioned taxon, whereas other (although from the morphological point of view this may look strange e.g. for J. hattorii Udar et V.Nath) treated in the last checklist as discrete species. Moreover, many taxa described by Stephani were merged to J. hutchinsiae ssp. javanica (e.g. J. rostrata Steph., J. sikkimensis Steph., J. tonkiensis Steph.) following to Guerke (1978). Most probably this issue requires further study involving molecular-genetic researches. The only taxon of Jubula recorded for the Russian Far East is J. japonica that treated as J. hutchinsiae subsp. japonica (Steph.) Horik. et Ando in Söderström et al. (2016). However, taking into account the poor understanding of difference between species and subspecies rank within Jubula I prefer to treat this taxon as the distinct species.

Jubula japonica Steph., Bull. Herb. Boissier 5(2):92, 1897 (Figure 1, 2:A)

Description. Plants merely soft, prostrate, $1.0-1.4 \mathrm{~mm}$ wide and 15-30 $\mathrm{mm}$ long, dirty green to pale yellowishgreenish, in loose mats, commonly associated with mosses. Rhizoids absent to numerous, in rigid brownish, erect spreading fascicles, closely attaching plants to the substratum. Stem freely pinnately branched (branches of Frullania type); cross section of well developed stems $170-180 \mu \mathrm{m}$ in diameter, outer cells thick-walled, walls with visible median lamina, 12-22(-25) $\mu \mathrm{m}$ along margin, inside thin-walled, 15$23 \mu \mathrm{m}$ in diameter, with vestigial trigones. Leaves imbricate; dorsal lobe obliquely to subhorizontally oriented, slightly convex, with apex distinctly curved to ventral side, densely dentate-ciliate, $600-800 \times 280-600 \mu \mathrm{m}$, smaller leaves with dorsal lobes not ciliate, with only attenuate-pilose apex; ventral lobe pyxidate, slightly longer than wide, lobe axis at $15-60(-80)^{\circ}$ with stem axis, ca. $180-200 \times 150 \mu \mathrm{m}$, almost invariable in size across the shoot despite considerable variations in the dorsal lobe size, stilus virtually absent to reduced to slime-papilla. Underleaves contiguous to slightly overlapping above situated underleaves, sinuously inserted, with hardly auriculate base, appressed to the stem or narrowly obliquely spreading, small underleaves nearly rectangular, ca. $350 \times 200 \mu \mathrm{m}$, with sinus descending to $3 / 5$ of the length, margin entire or with additional teeth in one or both lateral sides, some small underleaves are similar to larger underleaves that are widely ovate to $800 \times 700 \mu \mathrm{m}$ (excluding cilia), densely ciliate-dentate throughout, divided by $\mathrm{V}$ - to U-shaped sinus descending to $1 / 2$ of the length into 2 prominently apiculate lobes. Cells in dorsal lobe middle subisodiametric to oblong, 20-35 × 12-25 $\mu \mathrm{m}$, thin-walled, with small concave trigones, cuticle smooth, intermediate thickenings absent or obscure and present in lower half of the lobe; oil bodies ellipsoidal to shortly fusiform, nearly filling cell lumen, distinctly biconcentric. Autoicous. Androecia on short lateral branch, bracts cupped, imbricate, bilobed for 1/3-1/2 of the length, margin entire or remotely dentate, bracteole ovate, shortly incised. Perianth terminal on leading axis, distinctly plicate in upper half ( 2 ventral and 2 lateral folds), obscurely beaked, exerted for $1 / 2-3 / 4$ of the length, obconical-obovate, ca. $1.7 \times 0.6 \mathrm{~mm}$; bracteole narrowly ellipsoidal, shortly incised, bracts bilobed, lobes lanceolate, unequal, with margin dentate, but not ciliate.

Comment. This species is easily to recognize due to pixydate ventral lobe and ciliate leaves and underleaves. Probably it may be mistaken with Frullania and Neohattoria in regional flora due to pyxidate ventral lobe, however it easily differs from regional Frullania in ciliate leaves and underleaves and in larger size of plants and relatively large underleaves, as well as not caducous ventral lobe from Neohattoria.

Ecology. Within the Russian Far East this species is restricted to the southern flank of Primorsky Territory being known from two localities (with distance between them ca. $50 \mathrm{~km}$ ), both are in broadleaved forest with slight admixture of conifers (Pinus koraiensis Siebold et Zucc., Abies nephrolepis (Trautv. ex Maxim.) Maxim.) in lower altitude over humus on slope to stream in partial shade (cf. Bakalin 2010). The common companion of the taxon is the south-temperate East Asian moss Hypopterygium flavolimbatum Müll. Hal., another rarity in the bryophyte flora of the Russian Far East.

Distribution. The species is distributed mostly in Japan (from Honshu to Ryukyu) (Yamada \& Iwatsuki 2006), being rarity in Korean Peninsula (Choi 2013), sparse in Eastern China (Piippo 1990) and southernmost flank of the Russian Far East, where recorded only in Primorsky Territory. Within the Russian Far East it is restricted to lowlands, not surpassing $400 \mathrm{~m}$ a.s.l. (Fig. 3: A).

Neohattoria Kamim., J. Jap. Bot. 37(7):218, 1962

Neohattoria as it currently accepted, is monotypic genus (Söderström et al. 2016), with the only species $-N$. herzogii. 

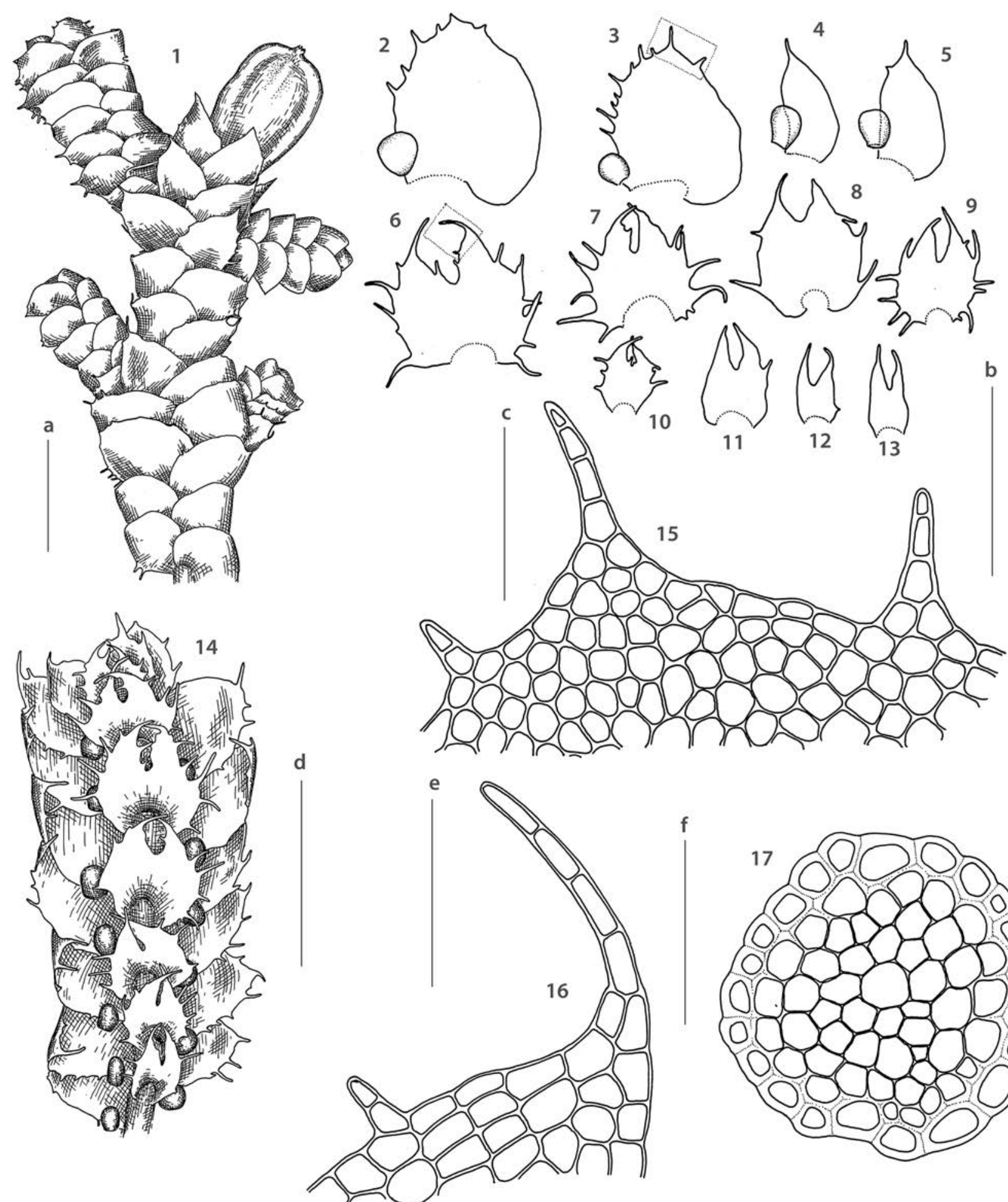

Figure 1 Jubula japonica Steph.: 1 - habit, dorsal view; 2-5 - leaves; 6-13- underleaves; 14 - shoot fragment, ventral view; 15 - leaf dorsal lobe apical part; 16 - underleaf lobe apical part; 17 - stem cross section. Scales: $\mathrm{a}-1 \mathrm{~mm}$, for 1; b - $1 \mathrm{~mm}$, for 2-13; c - $100 \mu \mathrm{m}$, for 15 ; $\mathrm{d}-1$ $\mathrm{mm}$, for 14; e $-100 \mu \mathrm{m}$, for 16; f - $100 \mu \mathrm{m}$, for 17. All from P-20-22-12 (VBGI)

The genus is easily recognized among regional taxa due to dentate to shortly ciliate dorsal leaf lobe, pachydermous cells in the dorsal lobe, pyxidate and easily caducous ventral lobe, vestigial to commonly obsolete stylus-like structure.

Neohattoria herzogii (S. Hatt.) Kamim., J. Jap. Bot. 37(7): 218, 1962 (三 Frullania herzogii S. Hatt., Feddes Repert. Spec. Nov. Regni Veg. 58:53, 1955) (Figure 2: B, 4: A, 5)

Description. Plants tiny, yellowish brownish to yellowish greenish, in loose mats, merely soft and gentle, loosely attached by rhizoids to the substratum, 350-500 $\mu \mathrm{m}$ wide and 3-6 mm long. Rhizoids virtually absent or solitary in shoot base, originating from underleaf bases. Stem brownish, freely laterally branched (branching of Frullania type), or with some, rarely occurring, ventral branches that become depauperate after 500-700 $\mu \mathrm{m}$, or with lateral subfloral innovations; cross section of well developed stems ca $75 \mu \mathrm{m}$ in diameter, with thickened cell walls, slightly becoming larger inward, with ca 15 cell rows in outer layer and 8-9 


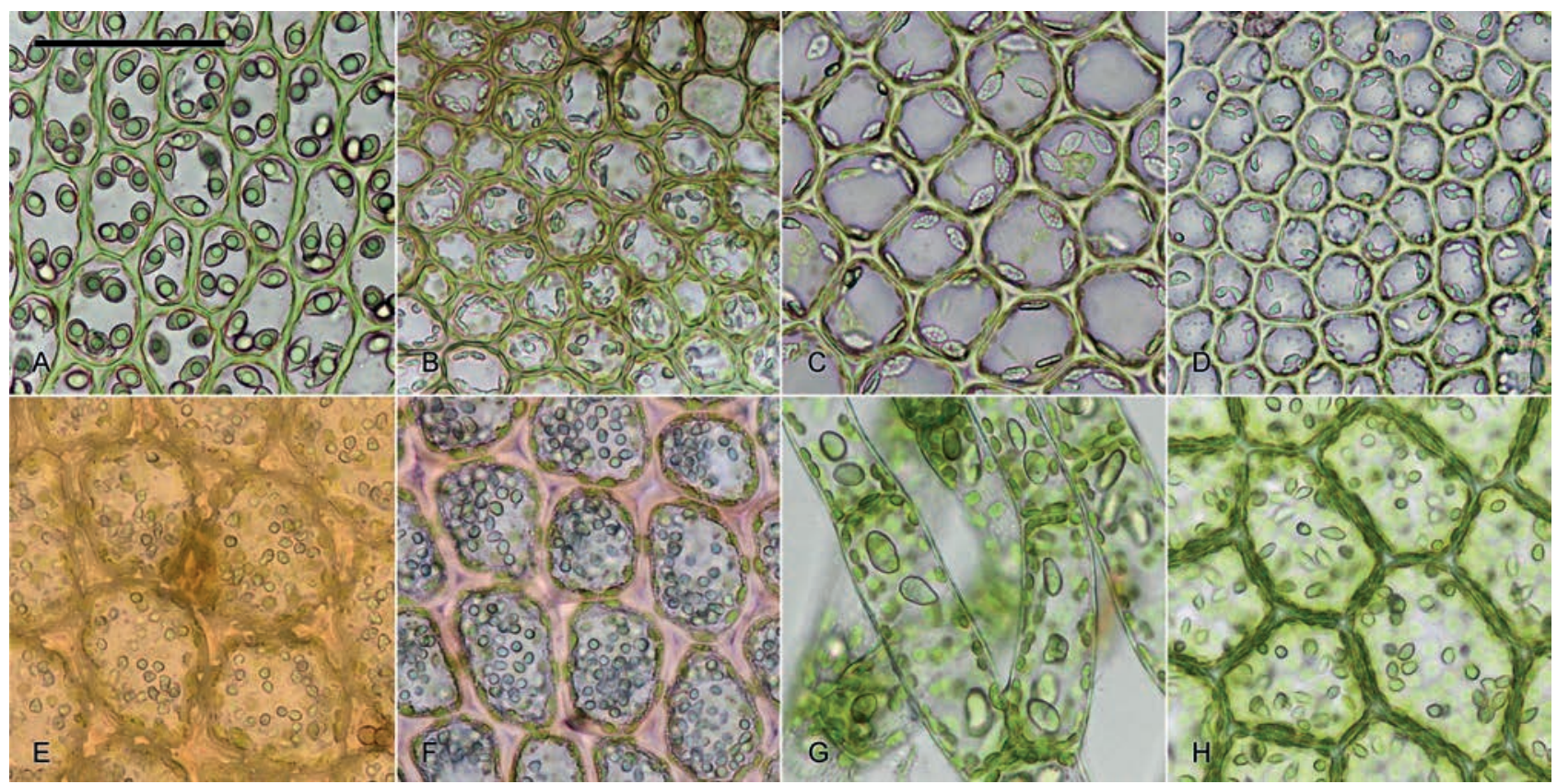

Figure 2 Oil bodies photographs: A - Jubula japonica Steph. (J-4-24-15, VBGI); B - Neohattoria herzogii (S.Hatt.) Kamim. (K-69-14-15, VBGI); C - Nipponolejeunea pilifera (Steph.) S. Hatt. (K-71-6-15, VBGI); D - Nipponolejeunea subalpina (Horik.) S. Hatt. (K-87-4-15, VBGI); E - Ptilidium ciliare (L.) Hampe (Khab-53-7-18, VBGI); F - Ptilidium pulcherrimum (Weber) Vain. (Kh-22-20-15, VBGI); G - Trichocolea tomentella (Ehrh.) Dumort. (J-8-21-15, VBGI); H - Trichocoleopsis sacculata (Mitt.) S. Okamura (P-34-24-14, VBGI). Scale: $50 \mu \mathrm{m}$

rows inward. Leaves subimbricate, dorsal lobe obliquely to subtransversely inserted, slightly convex, 220-330 $\times$ 170-300 $\mu \mathrm{m}$, when flattened in the slide obliquely ovate, margin densely dentate, especially so in ventral half, teeth 1-2-celled, or slightly longer and somewhat cilia-like; ventral lobe pyxidate, easily caducous, $130-230 \times 70-130 \mu \mathrm{m}$; stilus obsolete or highly reduced. Underleaves regular, 200$250 \times 100-120 \mu \mathrm{m}$, divided by U-shaped narrow sinus into two equal to strongly unequal lobes, sinus descending to $1 / 2-2 / 3$ of underleaf length, lobes straight to somewhat falcate, sublinear to narrowly triangular, acute. Cells in lobe middle subisodiametric, 13-20 $\mu \mathrm{m}$ in diameter, thin-walled, with large, convex trigones, cuticle smooth; oil bodies nearly smooth, 4-10 per cell, fusiform to shortly fusiform, compressed, biconcave. Dioicous? (Androecia not known). Unfertilized archegonia situated on the leading axis with 2-4 pairs of bracts, bracts distinctly differs from leaves in larger size and not pyxidate ventral lobe, bracteole only for $1 / 3$ of the length bilobed.

Comment. The taxon is very easily identified due to comparatively large (ca $1 / 2-2 / 3$ of dorsal lobe length) and caducous ventral lobe, as well as dentate leaf margin. The species is superficially similar to Nipponolejeunea subalpina due to dentate-ciliate dorsal lobe margin and small size. However, two taxa are easily differentiated by ventral lobe that is pyxidate and caducous in Neohattoria and nearly ovate and plane in Nipponolejeunea. Besides, cilia salong dorsal lobe margin are much more prominent and along than those in Neohattoria.

Ecology. This is obligate epiphytic taxon growing on partially shaded bark of Abies, Picea, Taxus, Betula and broadleaved trees in mixed to coniferous forests in areas under humid climate.

Distribution. Mainly Japanese oroboreal to oro-hemiboreal species distributed in northern half of Japan (Hok- kaido and Honshu, cf. Yamada \& Iwatsuki 2006), southernmost Kurils and several closely situated localities in southern Khabarovsk Territory (Fig. 3:A). The record from Khabarovsk Territory at $51-52^{\circ} \mathrm{N}$ looks enigmatic if no florogenetic reasons would be taken into account. The latter was discussed mainly for the purpose of exchange of Japanese alpine flora and alpine floras of North-East Asia via Sakhalin and northern Sikhote-Alin by land bridges in the glacioeustatic variations (Bakalin 2015). The same certainly is likely possible for oroboreal taxa too. Neohattoria herzogii may be one of the most striking examples of this group. This may explain absence of the species in the southern part of Sikhote-Alin (where the species however may be recorded), Korean Peninsula and suggest expectations of the taxon in Sakhalin Island. Another example of the same pattern is Ptilidium californicum distribution in the Russian Far East (see below). Due to the current data the gap between the nearest localities in Hokkaido and southernmost occurrences in Khabarovsk Territory is over $700 \mathrm{~km}$.

Nipponolejeunea S. Hatt., Bull. Tokyo Sci. Mus. 11:124, 1944

Nipponolejeunea includes two species of amphi-Pacific East Asian distribution; both are occuirred in the southernmost latitudes of the Russian Far East. The genus is characterized by pycnolejuneoid subfloral innovations, perianth with maximum 2 archegonia (Frey \& Stech 2009). Among regional taxa the genus is distinctive due to ciliate (at least at apices) dorsal lobes, ventral lobe nearly ovate and appressed to dorsal one, somewhat caducous leaves in some phases of $N$. subalpina. The genus belongs to Jubulaceae, as it was showed by Larraín et al. (2015), despite it striking contrast in ventral lobe morphology. The controversial morphology with some traits similar to Jubula and some related to Lejeuneaceae reflected in previous placement of this 


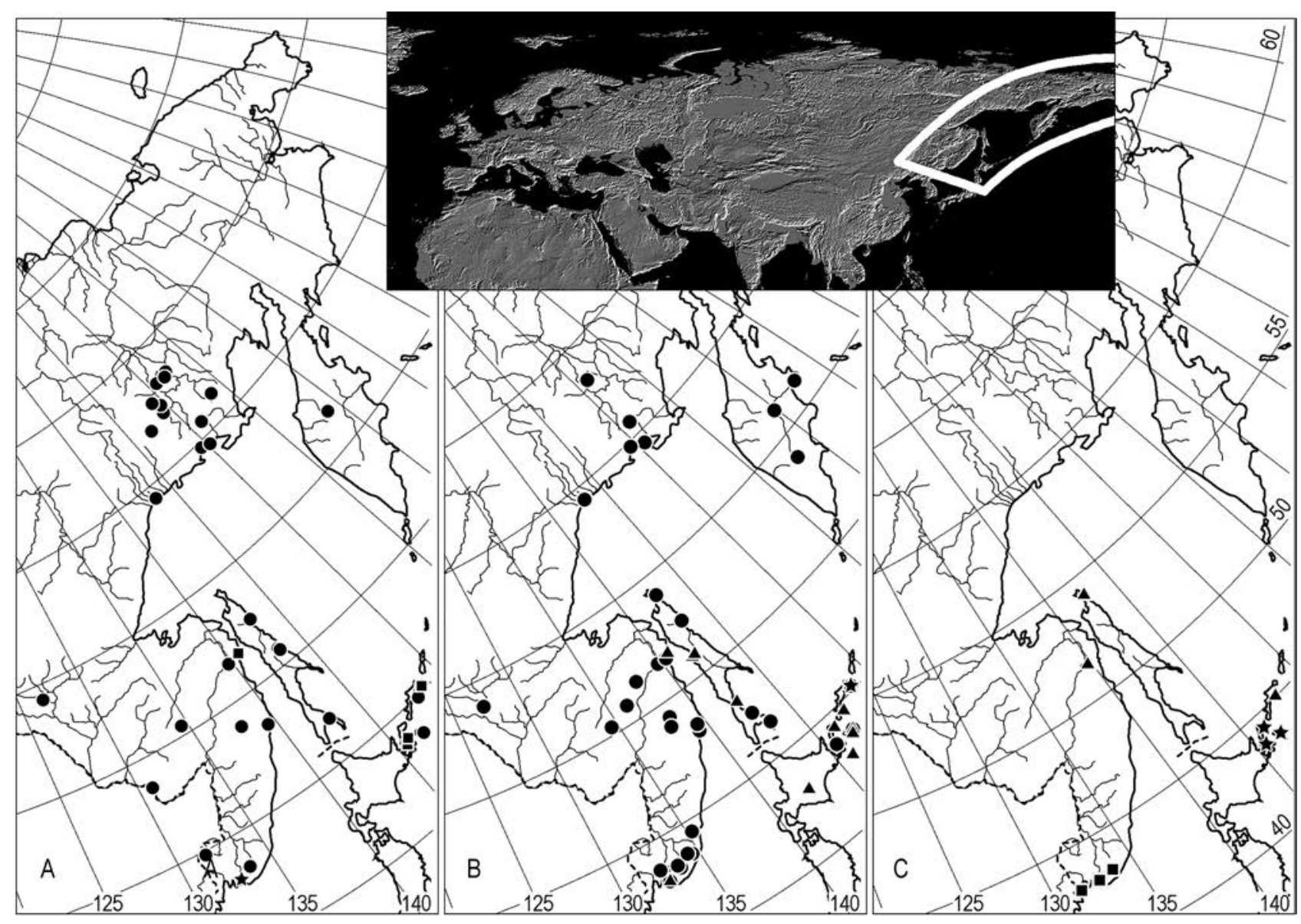

Figure 3 The distribution of taxa with ciliate leaves in the Russian Far East based on specimens examined. A: Jubula japonica Steph. - asterisk; Neohattoria herzogii (S.Hatt.) Kamim. - squares; Ptilidium ciliare (L.) Hampe - circles. B: Nipponolejeunea pilifera (Steph.) S. Hatt. - asterisk, N. subalpina (Horik.) S. Hatt. - triangles, Ptilidium pulcherrimum (Weber) Vain - circles. C: P. californicum (Austin) Pearson - triangles, Trichocolea tomentella (Ehrh.) Dumort. - asterisks, Trichocoleopsis sacculata (Mitt.) S. Okamura - squares.

genus into the special subfamily Nipponolejeuneoideae R.M. Schust. \& Kachroo within Lejeuneaceae or even the treatment all Jubulaceae under Jubuloideae Schiffn. in Lejeuneaceae. This genus was widely distributed in the past, at least in Laurasia (Nipponolejeunea europaea Grolle from Eocene Baltic amber) and the genus is "stenoevolutionary taxon, which apparently remained morphologically unchanged during at least ca. 30-50 mio.y." (Frey \& Stech 2009: 94). The extant taxa of Nipponolejeunea may be keyed out by as following:

1. Plants $0.4-0.6 \mathrm{~mm}$ wide, leaves commonly caducous, cilia in dorsal lobe 3-6 cells long.

N. subalpina

1. Plants $1.2-1.8 \mathrm{~mm}$ wide, leaves never caducous, cilia in dorsal lobe $5-12$ cells long ..

N. pilifera

Nipponolejeunea pilifera (Steph.) S.Hatt., Bull. Tokyo Sci. Mus. 11:125, 1944 (三 Pycnolejeunea pilifera Steph., Sp. Hepat. (Stephani) 5:624, 1914) (Figure 2: C, 4: B, 6)

Description. Plants greenish-yellowish to whitishgreenish, merely rigid, in dense patches or loosely covering substrate, $1.2-1.8 \mathrm{~mm}$ wide, $15-30 \mathrm{~mm}$ long (longer if to include decayed basal portion). Rhizoids virtually absent. Stem sparsely pinnately branched, branches of Frullania type; cross section of well-developed stems nearly circular, ca $180-190 \mu \mathrm{m}$ in diameter, outer cells very thick-walled, $17-25 \mu \mathrm{m}$ in diameter, with large trigones, not or loosely differentiated from inner cells, where cells become thinwalled, 20-30 $\mu \mathrm{m}$ in diameter, with large trigones. Leaves imbricate; dorsal lobe convex, with apical part turned to ventral side, when flattened in the slide obliquely ovate, only slightly larger than underleaves, 1.0-1.2 ×0.9-1.1 mm, with apex nearly rounded, but with prominent cilia also in the apical point that makes aspect of acutely pointed leaf lobe, cilia 0-7 per dorsal lobe, present in apical part only, 5-10(-12) cells long, apical cell longer than below situated ones and with thin walls, cilia 200-300(-400) $\mu \mathrm{m}$ long; ventral lobe plane to slightly convex or concave, obliquely quadrate, ca $400 \times 300 \mu \mathrm{m}$, the first tooth obtuse, 1-celled, or 2 cells in base and 2 cell high, the second tooth $1-2$ cells in the base and 2-3 cells long. Underleaf overlapping 1/3$1 / 2$ of above situated underleaf, appressed to the stem or slightly recurved to squarrose, sinuately inserted, transversely elliptic to loosely cordate, divided by narrowly $\mathrm{V}$-shaped sinus descending to $1 / 3-2 / 5$ of underleaf length into 2 obtuse to acute lobes overlapping in margins, $0.5-0.6 \times$ 0.8-1.1 mm, margin entire. Cells in dorsal lobe middle subisodiametric, 20-30 $\mu \mathrm{m}$ in diameter, thin-walled, with large to moderate, convex to Y-shaped trigones, cuticle smooth, intermediate thickenings absent (sparsely present in lower half of the lobe); oil bodies coarsely granulate, 2-3 per cell, fusiform. 


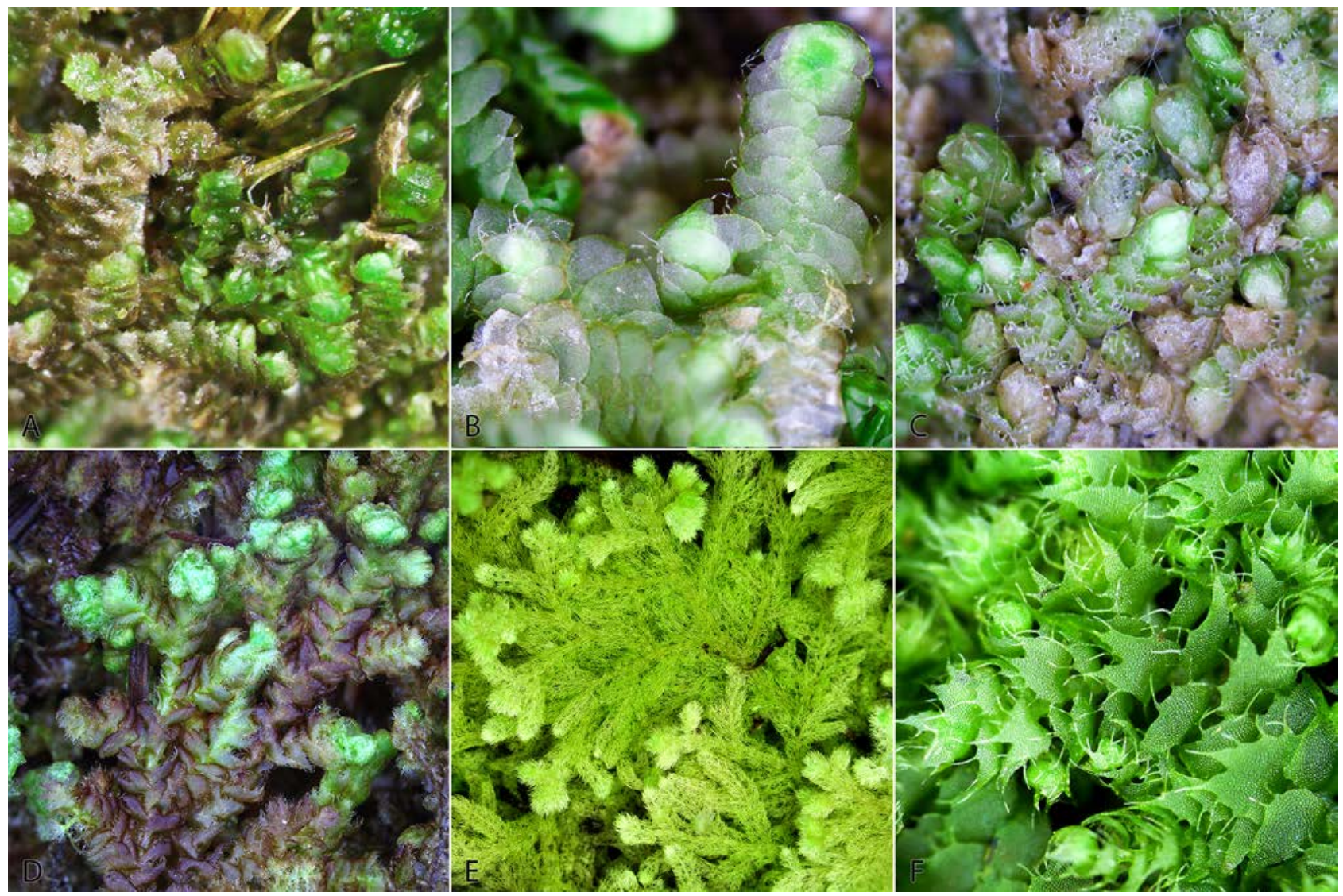

Figure 4 Plant habit photographs: A - Neohattoria herzogii (S.Hatt.) Kamim. (K-69-14-15, VBGI); B - Nipponolejeunea pilifera (Steph.) S.Hatt. (K-71-15-15, VBGI); C - Nipponolejeunea subalpina (Horik.) S.Hatt. (K-87-4-15, VBGI); D - Ptilidium ciliare (L.) Hampe (Khab-53-7-18, VBGI); E - Trichocolea tomentella (Ehrh.) Dumort. (J-11-23-15, VBGI); F - Trichocoleopsis sacculata (Mitt.) S. Okamura (P-34-24-14, VBGI)

Comment. The species is easily distinguished due to relatively large size, ciliate dorsal lobe apex, bidentate ventral lobe and regular, narrowly divided underleaves. The species differs from Nipponolejeunea subalpina in larger size, longer cilia and not caducous leaves.

Ecology. In the most extent of the area (Japan, Korean Peninsula) this is obligate epiphytic mesophyte, however, in the only area where it is known in Russia (Iturup Island) it possesses epilithic nature where occupies open to partly shaded tufa cliffs in lower altitudes surrounded by Betula ermanii Cham. forest with dense Sasa understory. The associates include both temperate East Asian Frullania appendiculata Steph., as well as more northerly distributed Doninia plicata (Lindb.) Konstant. et Vilnet.

Distribution. Mainly Japanese-Korean oro-hemiboreal to oro-temperate endemic, known from Hokkaido to Kyushu in Japan (Yamada and Iwatsuki, 2006), sparsely occurring in southern half of Korean Peninsula (Choi 2013) and stretching area southward to Taiwan (Piippo 1990). Northwardly known in southern Kurils (Iturup) (Fig. 3:B). Taking into account the general distribution of the taxon, the record in northern part of Iturup Island was quite unexpected because of its absence southward in southern part of Iturup Island as well as southwardly situated Kunashir and Japanese Hokkaido. The occurrence of Nipponolejeunea in Iturup, i.e. among vegetation of rather boreal character, presumably possesses relict nature. The latter may also find the confirmation in unusual occurrence of this epiphytic species on acidic tufa cliffs. The reason for survival of this more southern species under colder condition I could see may be the effect of insularity.

Nipponolejeunea subalpina (Horik.) S.Hatt., Bull. Tokyo Sci. Mus. 11:125, 1944 (三 Pycnolejeunea subalpina Horik., J. Jap. Bot. 15:360, 1939) (Figure 2:D, 4:C, 7)

Description. Plants tiny, creeping over bark of trees to that commonly densely attached by rhizoids, 400-600 $\mu \mathrm{m}$ wide, 4-10 mm long, in loose patches. Rhizoids virtually absent to abundant, originating from underleaf bases, erect spreading, in nearly colorless fascicles. Stem freely pinnately branched (branching of Frullania type), also as subfloral innovations; cross section of well developed stems ca $100 \mu \mathrm{m}$ in diameter, nearly circular in outline, outer cells $12-15 \mu \mathrm{m}$ in diameter, inner slightly larger, to $23 \mu \mathrm{m}$ wide, throughout the section with unequally thickened walls and large trigones. Leaves imbricate to contiguous, easily deciduous (although underleaves persistent); when wet dorsal lobe erect spreading, dorsal lobe convex, when flattened in the slide $230-420 \times 180-300 \mu \mathrm{m}$, obliquely ovate, in small leaves margin entire with acute apex, but commonly with 1 (then apical only) to several (apical and dorsal margin) cilia and additional teeth between them, cilia 3-6 cells long, teeth 1-2 cells in the base and 2-3 cells long; ventral lobe slightly smaller than dorsal lobe, appressed to the dorsal lobe, slightly concave to slightly convex, 170-260 


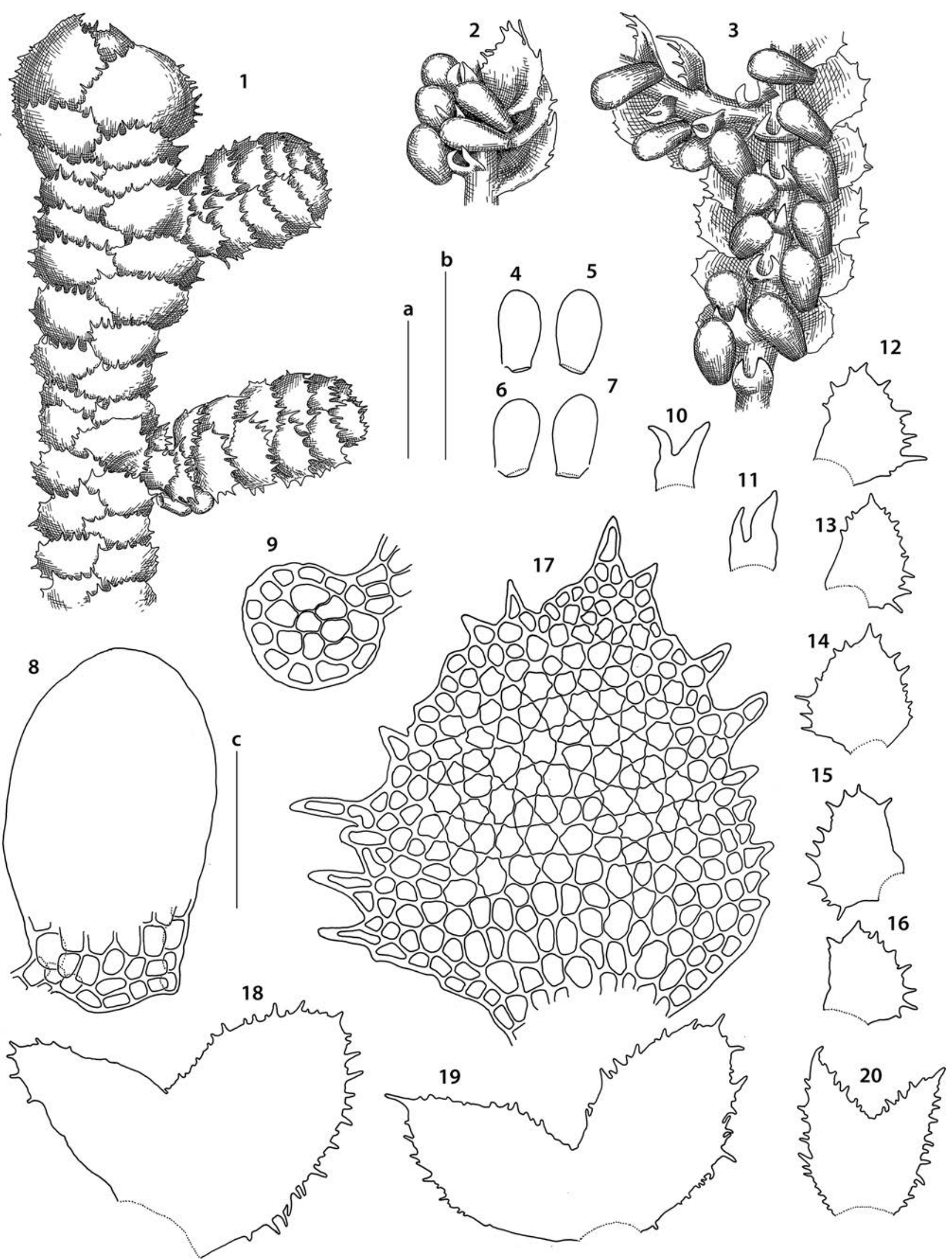

Figure 5 Neohattoria herzogii (S. Hatt.) Kamim.: 1 - habit, dorsal view; 2, 3- shoot ventral view, fragments; 4-8 - ventral lobes; 9 - stem cross section (with leaf origin area); 10, 11 - underleaves; 12-17 - dorsal lobes; 18, 19 - female bracts; 20 - female bracteole. Scales: a - 500 $\mu$ m, for 1 ; $b-500 \mu \mathrm{m}$, for 2-7, 10-16, 18-20; c- $100 \mu \mathrm{m}$, for 8, 9, 17. All from E. Roenko, 6 Aug. 2011 (VBGI)

$\times 150-200 \mu \mathrm{m}$, ovate to subquadrate, with 2 teeth in apical part, teeth obtuse to acute (cilia like) $1(-2)$ cells in the base and 1-3(-4) cells long. Underleaves 120-170 × 150-
$230 \mu \mathrm{m}$, appressed to the stem, persistent, divided by $\mathrm{V}$ to U-shaped sinus descending to $1 / 3-2 / 5$ of underleaf length into 2 obtuse to merely acute lobes, lateral side 

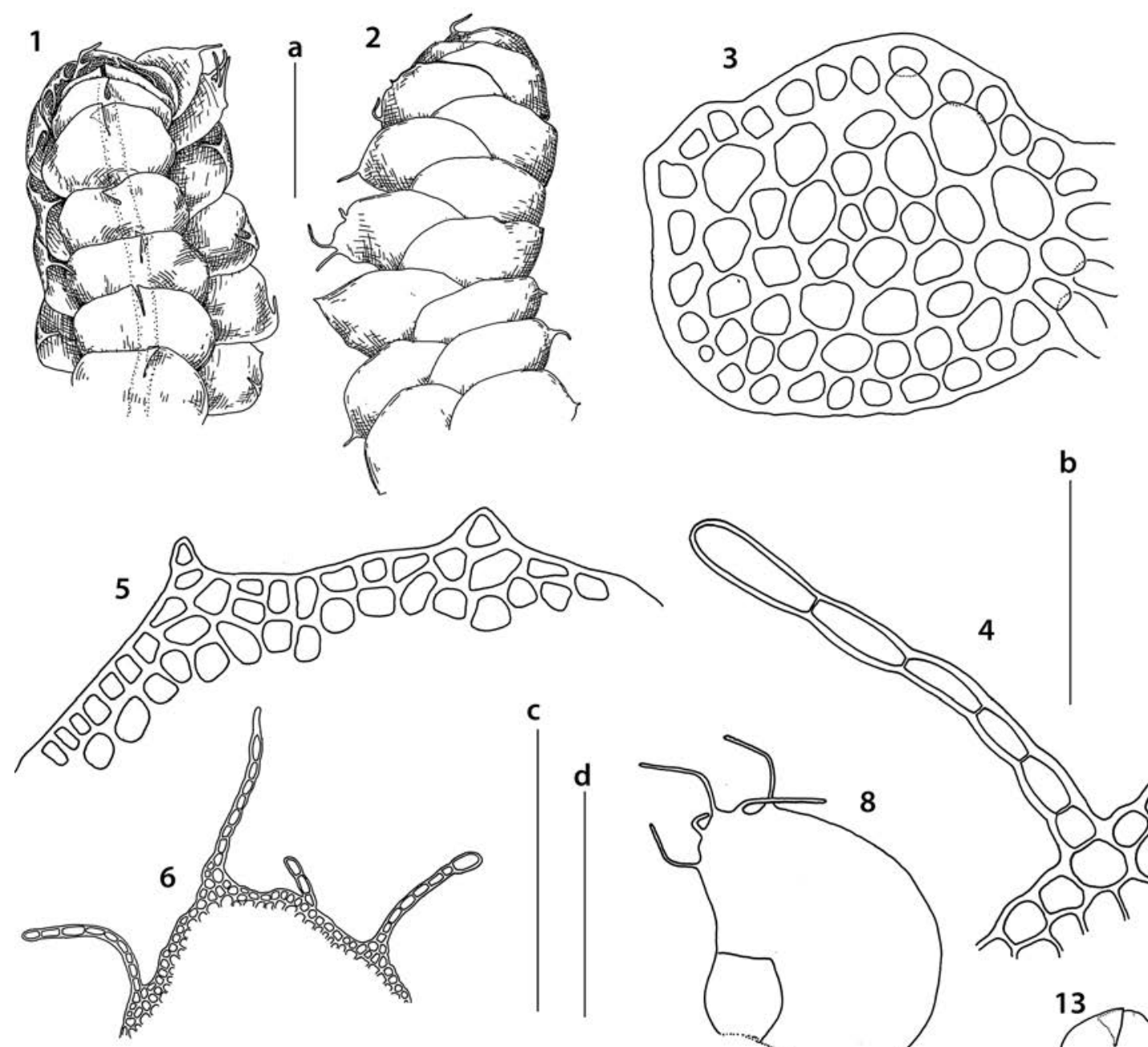

7

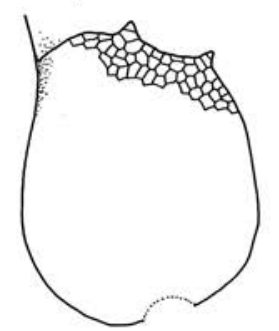

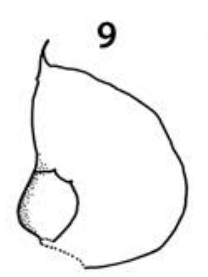

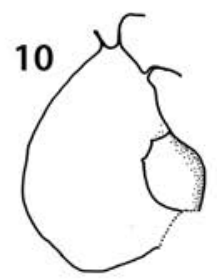

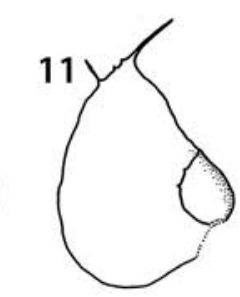
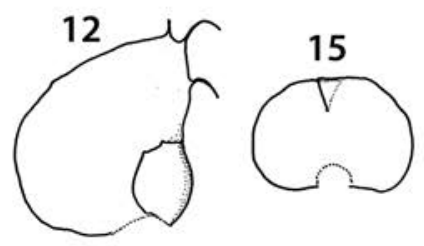

14

13
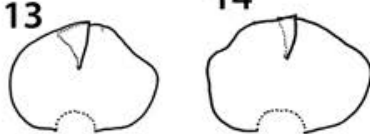

b
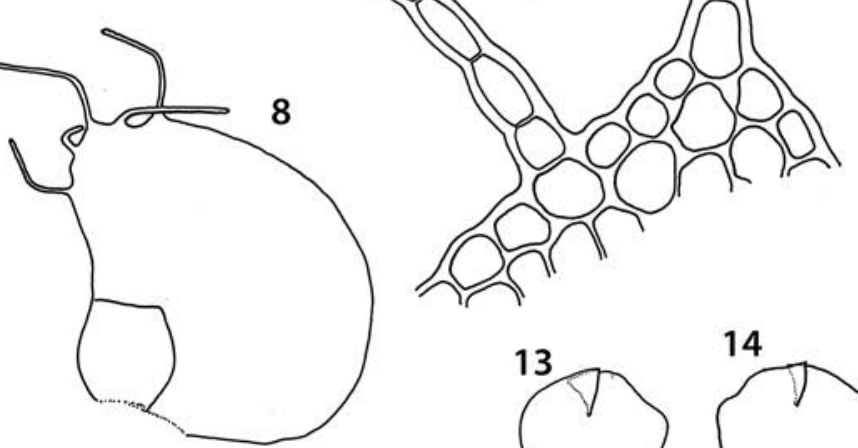

ר

Figure 6 Nipponolejennea pilifera (Steph.) S.Hatt.: 1 - habit, ventral view; 2 - habit, dorsal view; 3 - stem cross section (with leaf origin area); 4, 6- leaf dorsal lobe apex; 5 - leaf ventral lobe apex; 7 - ventral lobe; 8-12-leaves; $13-16$ - underleaves. Scales: a - 1 mm, for 1,2, 9-16; $\mathrm{b}-100 \mu \mathrm{m}$, for 3-5; c - 500 $\mu \mathrm{m}$, for 6, 7; d $-1 \mathrm{~mm}$, for 8. 1, 2, 5, 7, 9-16 from K-71-12-15; 3, 4, 6, 8 - from K-71-6-15 (all in VBGI)

entire or with 1 obtuse teeth in each side. Cells in dorsal leaf lobe middle subisodiametric, $12-18 \mu \mathrm{m}$ in diameter, thin-walled, with triangular to concave, moderate to small trigones, intermediate thickenings sparsely present to common, cuticle smooth; oil bodies finely granulate, 2-4 per cell, oblong to fusiform. Dioicous. Perianth terminal, with 0-2 subfloral innovations, ovate, 3-plicate (2 lateral, 1 ventral folds), loosely beaked, ca. $0.5 \times 0.4 \mathrm{~mm}$, exerted for $1 / 5-1 / 3$ of the length; female bracts with subequal lobes, dentate, but not ciliate.

Ecology. Epiphytic mesophyte occurring on tree trunks of broadleaved and coniferous trees (especially thin trunks of Abies) and thin branches of shrubs (like Vaccinium ovalifolium Sm., shrubby form of Taxus cuspidata Siebold and Zucc., etc.). It occurs in oro-boreal or oro-hemiboreal belts of mountains in mixed to coniferous forests in partly shaded habitats. Southward of the Russian Far East the species occurs in similar belts. The species commonly forms pure patches, although sometimes growing mixed with other epiphytes like Neohattoria herzogii, Radula obtusiloba Steph. and, as rare variant, with Ptilidium pulcherrimum.

Distribution. Generally Japanese-broadly Manchurian hemiboreal taxon, rare in Korean Peninsula (Choi 2013) southwardly known from isolate locality in Taiwan (Piippo 1990). The term 'subalpina' is quite appropriate for the plants collected in Russian Far East, where the species occurs in southern part of Primorsky Territory, southern part of Khabarovsk Territory (spurs of northern Sikhote-Alin going to the Pacific Ocean coast), southern and middle parts of Sakhalin Island and southern Kurils (southward 


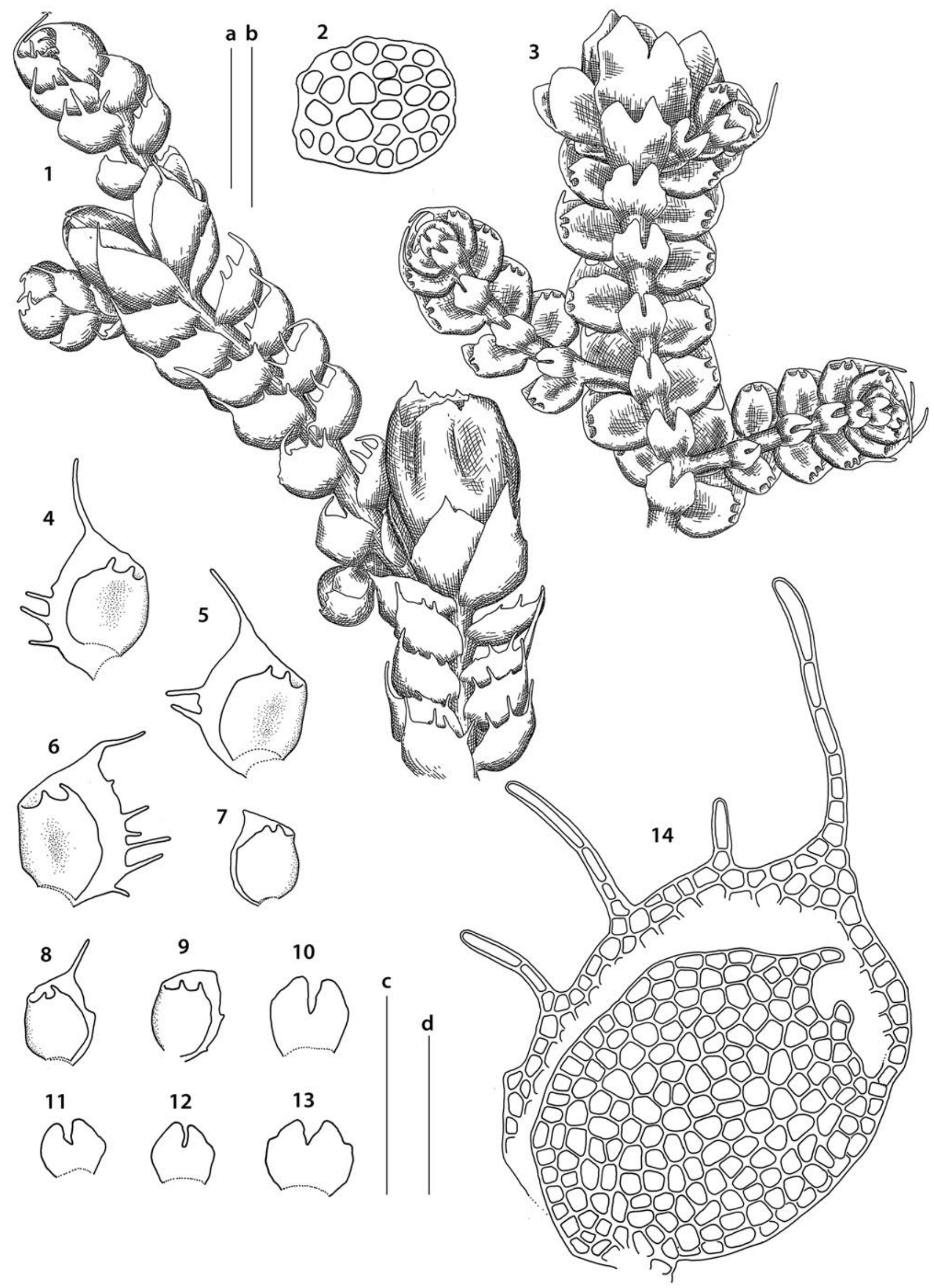

Figure 7 Nipponolejeunea subalpina (Horik.) S.Hatt.: 1 - habit, dorsal view; 2 - stem cross section; 3 - habit, ventral view; 4-9, 14 - leaves; 10-13 - underleaves. Scales: a - $500 \mu \mathrm{m}$, for 1, 3; b - $100 \mu \mathrm{m}$, for 2; c - $500 \mu \mathrm{m}$, for 4-13; d - $100 \mu \mathrm{m}$, for 14. All from S-48-7-16 (VBGI) 
of Urup Island) (Fig. 3:B). In the most cases the species does not rise above $300-400 \mathrm{~m}$ a.s.l., with the exception of oro-boreal occurrence in Livadijsky Range of Primorsky Territory (subalpine forest at $1300 \mathrm{~m}$ a.s.l.) and Picea jezoensis (Siebold \& Zucc.) Carrière forest in northern Kunashir (500 $\mathrm{m}$ a.s.l.). The distribution of the taxon marks the areas with high air moisture and the only reason for occurrence of this taxon in the upper elevations in Primorye is the higher air moisture in oroboreal belt of Sikhote-Alin than below. The similar effect I observed in South Korea, where the species was recorded only once in dense shrub thickets at ridge line above $1400 \mathrm{~m}$ a.s.l. that moistened by wet air masses going from Pacific and local fogs.

\section{Ptilidiaceae H. Klinggr}

This is small family counting three species within one genus only, all of them known in the Russian Far East. The real number of taxa may be higher, with one undescribed (probably cryptic) species occurring in Himalaya, as showed by Kreier et al. (2010). The family is characterized by 1-3 pinnate branched stem (branching Frullania type, that is not always obvious because ventral half of leaf commonly remains not reduced), transversely inserted and incubously oriented leaves, leaves 3-4-lobed and ciliate (scarcely to densely), relatively large cells (over $30 \mu \mathrm{m}$ in diameter), with coarsely bulging trigones, oil bodies small, homogenous to finely botryoidal, numerous, perigynium absent, perianth long-exerted, capsule wall 4-6-stratose, elaters bispiral, spores spherical, papillose, gemmae and other specialized vegetative propagules absent. The representatives of the family are distributed over boreal and hemiboreal zones and corresponding mountain belts in the northern hemisphere, apart of Ptilidium ciliare, occurring in Arctic and southward of $35^{\circ} \mathrm{N}$ (even in mountains), there are several records in southern hemisphere (New Zealand, Tierra del Fuego). Within the Russian Far East Ptilidiaceae are common component of plant communities northward of $50^{\circ} \mathrm{N}$, southward they are considerable rarer and occur in mountains only.

Ptilidium Nees, Naturgesch. Eur. Leberm. 1:95, 1833

The species of the genus may be keyed as following:

1. Plants robust, relatively rigid, (1.3-)1.5-2.8(-3.0) $\mathrm{mm}$ wide, leaves divided by sinus descending to $1 / 2$ of the leaf length, leaves distinctly wider than long, epilithic to epigeal (ground cover in tundras, subarctic forests, rarer peat moss raised bogs, etc.) plants, stem cross section with outer cells distinctly smaller than inner....

Ptilidium ciliare

1. Plants merely soft, mostly narrower $1.3-1.5 \mathrm{~mm}$ wide (rarely in suboceanic epiphyte $P$. californicum to $2.5 \mathrm{~mm}$ wide), leaves divided by sinus descending to $2 / 3-3 / 4$ of leaf length, leaves as wide as long, epiphytic to epixylous plants, very rarely occurring on mineral substrata, stem cross section with outer cells only slightly smaller than inner or nearly the same in size

2

2. Plants deeply colored, brown to yellowish brown and rusty, leaves with $0-3(-4)$ cilia per lobe; underleaves deeply divided [areas under oceanic climate]

Ptilidium californicum

2. Plants variously colored, from pale greenish to brown and rusty, never as deep as above, leaves with 5-15 cilia per lobe, underleaves only shortly emarginate to lobed with si- nus descending less $1 / 4$ of the underleaf length [widely distributed across area including oceanic, monsoon and continental climates]

Ptilidium pulcherrimum

Ptilidium californicum (Austin) Pearson, List. Canad. Hepat.: 7, 1890 (三 Lepidozia californica Austin, Bull. Torrey Bot. Club 6(3):19, 1875) (Fig. 8)

Description. Plants merely soft, pale rusty yellowishbrownish to commonly rusty brown in well exposed places, forming loose patches, $1.2-2.5 \mathrm{~mm}$ wide and $15-40 \mathrm{~mm}$ long. Rhizoids sparse, nearly colorless, from ventral side of stem, originating mostly near underleaf bases, but not only there, in erect spreading loose and short (less $500 \mu \mathrm{m}$ ) fascicles. Stem freely pinnately branched, brownish to brownish-yellowish; stem cross section somewhat transversely elliptic, ca $250 \times 180 \mu \mathrm{m}$, outer cells thick-walled, 12-25 $\mu \mathrm{m}$ along margin, with large to moderate in size trigones, inward become thinner, with moderate, concave trigones, 20-30 $\mu \mathrm{m}$ in diameter. Leaves contiguous to subimbricate, transversely inserted, incubously oriented, unequally (3-)4-lobed, divided by narrow $\mathrm{V}$-shaped sinus descending to $2 / 3-3 / 4$ of leaf length, with dorsal lobes larger, lobes narrowly triangular to lanceolate, cilia 0-3 per leaf lobe (in total leaf bear 3-6 cilia), lobes and cilia straight to somewhat falcate, leaves 1.0-1.5 × 1.0-1.5 mm. Underleaves regular, obliquely to almost erect spreading, varying in size (noticeable large underleaf may be associated with comparatively small leaves and vice versa), $500-1000 \times 425-850 \mu \mathrm{m}, 2-3$-lobed by sinus descending to $3 / 4-5 / 6$ of underleaf length, lobes $2-3$ cells wide in the base, densely ciliate. Cells in the middle of leaf lamina shortly oblong to subisodiametric, 30-58 $\times$ 25-38 $\mu \mathrm{m}$, thin-walled, with large, rarely confluent, convex trigones, with visible median lamina, cuticle smooth, cells in cilia 50-100 $\mu \mathrm{m}$ long. Dioicous. Perianth terminal on leading axis, with one subfloral innovation, ovate to obovate, loosely 3-5-plicate in upper half, densely ciliate in the mouth, with cilia 3-6 cells long, 3.5-4.5 × 1.2-2.0 mm; female bracteole robust, divided by sinus descending to $1 / 2$ of the length into 2-4 narrow and densely ciliate lobes; female bracts similar in size or smaller than bracteole, 1-3-lobed.

Comment. Due to its epiphytic and epixylous habitats the species may be mistaken with Ptilidium pulcherrimum, from which differs in larger size, not numerous cilia along leaf margin, deeply divided underleaves and bright color with common (if not obligatory) admixture of rusty pigmentation.

Ecology. Acidophilic mesophyte. Within the western North America (the main part of area of the species) it is known from epiphytic and epixylous habitats, rarely also occurring on rock surfaces and soil (Leonardi 2002). Within the Russian Far East the species is not found in other than woody substrates. It occurs on bark of trees (mostly Betula ermanii) and decaying wood in boreal to oro-hemiarctic (coniferous, mixed and stone birch) forests. The species is very sensitive to air moisture and occurs only in the areas with oceanic climate. It is growing in pure patches, although once it was collected together with Ptilidium pulcherrimum.

Distribution. Boreal amphi-Pacific taxon. The main area core is in western North America where the species is more malleable in ecology than in Asian part of area, where the distribution covers south of insular part of the Russian 


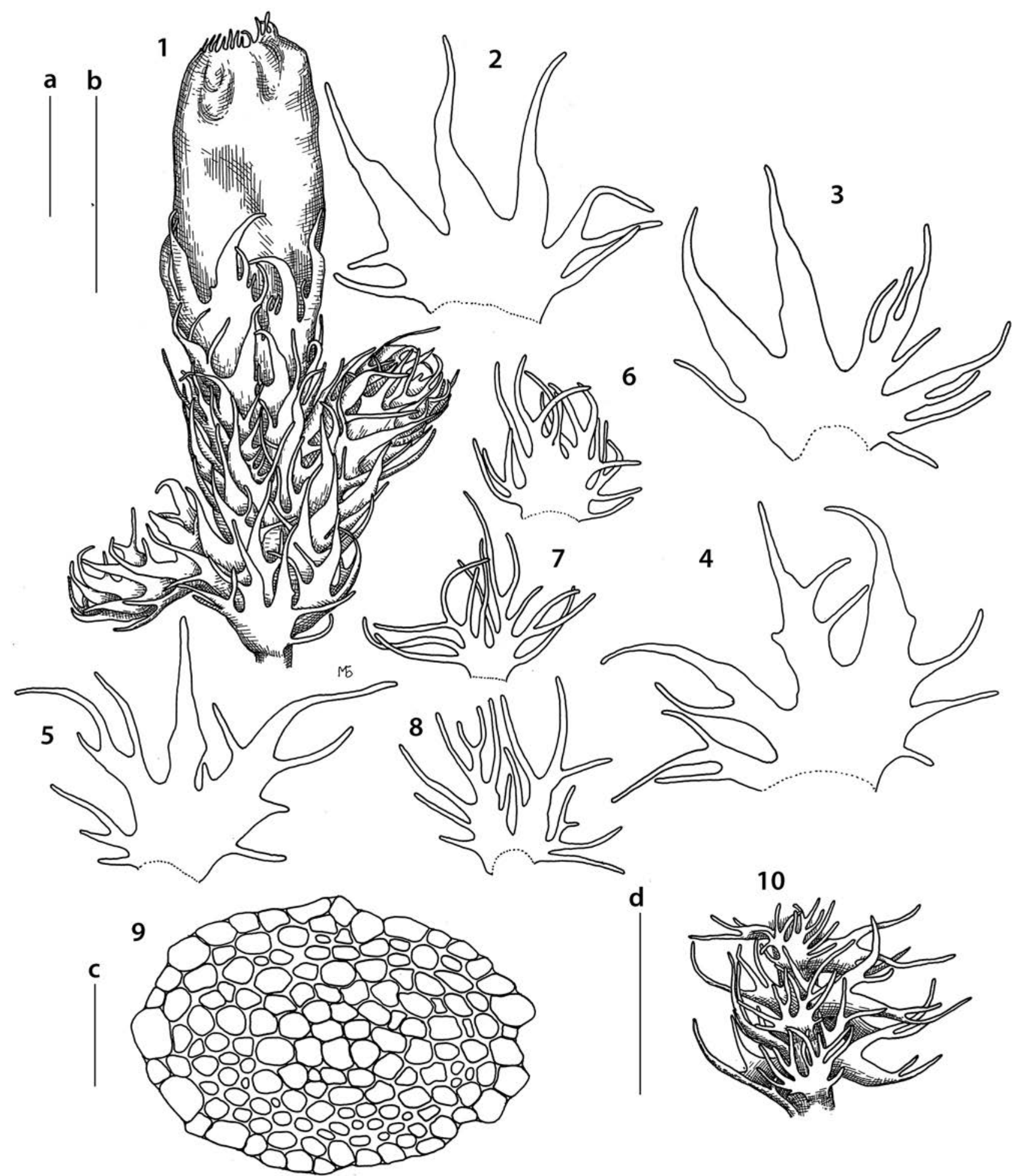

Figure 8 Ptilidium californicum (Austin) Pearson: 1 - habit, dorsal view; 2-5 - leaves; 6-8 - underleaves; 9 - stem cross section; 10 - shoot ventral view, fragment. Scales: $\mathrm{a}-1 \mathrm{~mm}$, for $1 ; \mathrm{b}-1 \mathrm{~mm}$, for 2-8; c $-50 \mu \mathrm{m}$, for 9; $\mathrm{d}-1 \mathrm{~mm}$, for 10. All from S-46-4-09 (VBGI)

Far East and Japan. The distribution of the species confirm the point of view by Iwatsuki (1972) who showed that East Asian relationships with Eastern North America ('EastEast' disjunction type) confined to temperate taxa, whereas relationships with Western North America are characteristic for boreal taxa. The distribution in the Russian Far East is restricted to strictly amphi-Pacific areas: northernmost Sikhote-Alin in Khabarovsk Territory, Schmidt Peninsula in North Sakhalin, East Sakhalin Mountains, Kurils, southern flank of Kamchatka, one locality in Commanders, everywhere the species occupies low to middle altitudes (Fig. 3:C). The distribution of this species is somewhat resembles that of Neohattoria herzogii discussed above. Whereas N. herzogii occurs in southern Kurils and then suddenly re-occurs in suboceanic areas of southern Khabarovsk Territory, the distribution of Ptilidium californicum marks this route also in northern Sakhalin. In Japan the species is known from Honshu (Yamada and Iwatsuki, 2006). 
Ptilidium ciliare (L.) Hampe, Prod. fl. hercyn.: 76, 1836 (三 Jungermannia ciliaris L., Sp. Pl. 1:1134, 1753) (Fig. 2:E, 4:D, $9: 1-6)$

Description. Plants merely rigid, in loose pure patches or together with other bryophytes, yellowish brownish to brown-red and blackish rusty, with color deeper in leaf apices, (1.3-)1.5-2.8(-3.0) $\mathrm{mm}$ wide and 25-80 $\mathrm{mm}$ long (longer in swampy forms). Rhizoids virtually absent or very few from ventral side of stem of depauperate shoots. Stem brownish, freely pinnately branched; cross section slightly transversely elliptic, ca $400 \times 500 \mu \mathrm{m}$, outer cells thickwalled, with moderate in size to large trigones, $12-23 \mu \mathrm{m}$ in diameter, inward become thin-walled, with moderate in size, concave trigones, $30-55 \mu \mathrm{m}$ in diameter. Leaves imbricate to contiguous, transversely inserted, incubously oriented, convex, unequally (3-)4(-5)lobed, divided by sinus descending to $1 / 3-1 / 2(-2 / 3)$ of leaf length, with dorsal lobes larger, lobes triangular, densely ciliate along margin, cilia commonly branched in the margins of the both bases, 1.2-1.6 $\times$ $1.5-2.0 \mathrm{~mm}$. Underleaves appressed to the stem, to narrowly spreading, when flattened in the slide transversely elliptic to reniform, with 3-several short lobes (sometimes present only as branched cilia), $0.7-1.0 \times 1.2-1.5 \mathrm{~mm}$. Cells in the middle of leaf lamina subisodiametric to shortly oblong, thin-walled, with large, convex to convex-concave trigones, with well-visible median lamina, 27-50 × 25-40 $\mu \mathrm{m}$; oil bodies 12-40 per cell, botryoidal to smooth, spherical 2.5 $3.5 \mu \mathrm{m}$ in diameter, to elliptic, $2.5-3.0 \times 3.0-4.5 \mu \mathrm{m}$; cells in the cilia $50-75 \mu \mathrm{m}$ long, cuticle smooth throughout.

Comment. This is large and beautiful species, well defined morphologically from other liverworts in the subarctic floras. The poorly developed phases of the species may be mistaken with Ptilidium pulcherrimum, from that $P$. ciliare differs in less divided leaf lobes and, in stem cross section, particularly strongly different outer cells from inner cells in size. Besides, in many cases the ecology helps to differ two taxa: P. ciliare was never occurred in decaying wood (only if that covered with thin layer of mineral soil) and cannot be true epiphyte. The only area where two taxa may meet one another is the trunk base, where $P$. pulcherrimum form compact patches attached to the bark of tree, whereas $P$. ciliare growing on soil surrounded tree trunk base. The species is somewhat malleable in morphology that concerns the number of cilia per leaf. In the most cases the leaf bears numerous (more than 20) cilia, but some forms from wet habitats (unusual to the species) the number may be much less, as it was occurred in Murmansk Province, where some plants had only a few cilia per leaf (Konstantinova, pers. comm.); the latter forms were not observed in our area. In southern extremes of the Russian Far East the species may be probably mistaken with Trichocoleopsis sacculata (Neotrichocoleaceae) the differentiation is under the latter.

Ecology. Acidophilic to neutrophilic mesophyte, occurring in various vegetation communities, from arctic tundras where among mesic moss patches in open places, including those along solifluction spots, merely dry to mesic slopes in lighted subarctic forests and krumholtz, open slopes with crumbling soil in boreal forests and their montane analogues. In upper altitudes in subarctic it goes above tundra belt and occurs in alpine deserts where restricted to crevices between stones along watercourses. Besides, everywhere through the area the species may occur on rather open cliff and the most southern occurrences of the species in lower altitude are from cliff crevices in broadleaved cool temperate forest in Primorsky Territory. In the north it occurs between huge rocks and in the crevices in stony fields above mountain tundra belt. The species commonly form pure patches, although sometimes occurs with meso-xerophytes like Barbilophozia barbata (Schmidel ex Schreb.) Loeske, Sphenolobus saxicola (Schrad.) Steph., S. minutus (Schreb.) Berggr. and Tetralophozia setiformis (Ehrh.) Schljakov. Although the species is dominantly possesses itself as acidophilic, it may grow at least in neutral and, rarely, even basic substrates, like those in limestone massif in Kolyma Upland, where Ptilidium ciliare was associated with Scapania simmonsii Bryhn \& Kaal. In moist neutral habitats of alpine belt it may be occurred with Trilophozia quinquedentata (Huds.) Bakalin. In the southern localities in low altitude the species may grow intermixed with temperate East Asian Frullania diversitexta Steph. Within the southernmost Kuirls the species once was occurred in low altitude in windy community under the thickets of East Asian Sasa, Eubotryoides grayana (Maxim.) H. Hara, etc. As an exotic habitat of the species may be regarded the occurrence above steaming hot spring with high sulfur content (Iturup Island), where the species grew together with Neoorthocaulis attenuatus (Mart.) L. Söderstr., De Roo \& Hedd.

Distribution. Arctoboreomontane circumpolar taxon with bipolar occurrences. Widely distributed in boreal and arctic zones of northern Hemisphere, southward of our area sparse in Japan (Hokkaido and Honshu, cf. Yamada \& Iwatsuki 2006), rare in northern part of Korean Peninsula (Choi 2013), sparse in North-East China (Gao \& Chang 1981). Within our area relatively common from the northern extremities (Fig. 3:A). In the north commonly occurs from near the sea level to relatively high altitudes, like over $1500 \mathrm{~m}$ a.s.l. in Kolyma Upland. In the southern part of our area almost exclusively occurs in stony fields above timberline, at the elevation exceeding $1300 \mathrm{~m}$ a.s.l. Below it becomes rare and occurs as exception in rocky outcrops down until even broadleaved forests. The lowest occurrence in Primorsky Territory is in mostly Quercus forest where the species was found in neutral reaction cliff ledges at $330 \mathrm{~m}$ a.s.l. In Shikotan Island (the similar latitude) the species was found in $320 \mathrm{~m}$ a.s.l. In southern part of our area the species occurs to the uppermost elevations available in the area treated (above $1900 \mathrm{~m}$ a.s.l.).

Ptilidium pulcherrimum (Weber) Vain., Meddel. Soc. Fauna Fl. Fenn. 3:88, 1878 (三 Jungermannia pulcherrima Weber, Spic. Fl. Goett.: 150, 1778) (Fig. 2:F, 9:7-14)

Description. Plants soft, in loose patches, varying from pale greenish to yellowish brown and golden brown, without distinct rusty, red or black pigmentation, 1.0-1.5(2.0) $\mathrm{mm}$ wide and $15-40 \mathrm{~mm}$ long. Rhizoids virtually absent to a few, in erect to obliquely spreading fascicles, less $400 \mu \mathrm{m}$ long. Stem pale yellowish to pale brownish, freely pinnately branched; stem cross section transversely elliptic, ca. $150 \times 200 \mu \mathrm{m}$, outer cells thick-walled, 25-30 $\mu \mathrm{m}$ 


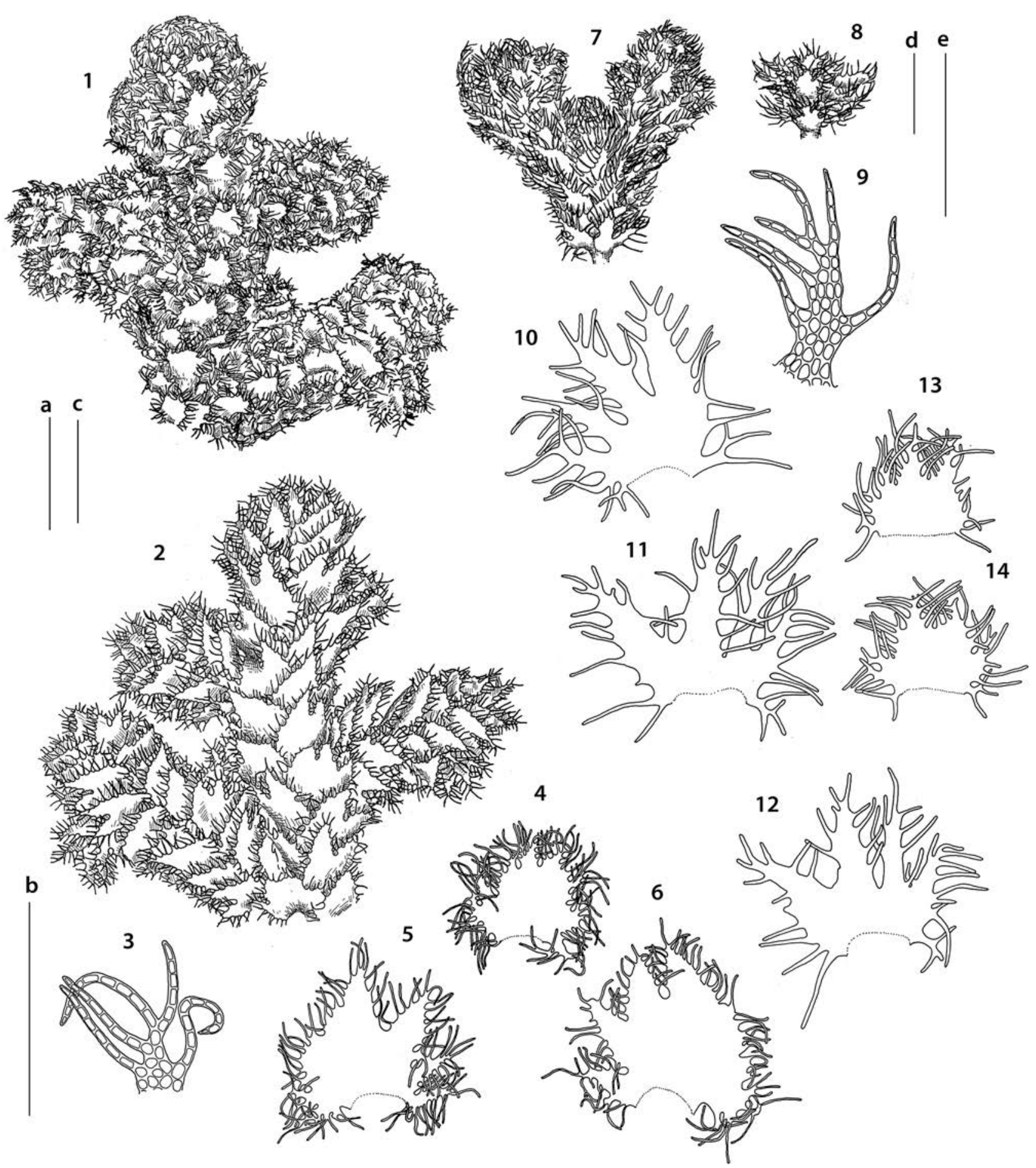

Figure 9 Ptilidium ciliare (L.) Hampe: 1 - habit, ventral view; 2 - habit, dorsal view; 3 - lobe apex; 4 - underleaf; 5, 6-leaves. All from Mag30-33-14 (VBGI). Ptilidium pulcherrimum (Weber) Vain.: 7 - habit, dorsal view; 8 - shoot ventral view, fragment; 9 - lobe apex; 10-12 - leaves; 13, 14 - underleaves. All from P-82-7-07 (VBGI). Scales: $\mathrm{a}-2 \mathrm{~mm}$, for 1, 2; b - 500 $\mu \mathrm{m}$, for 3, 9; c - $1 \mathrm{~mm}$, for 4-6; d $-1 \mathrm{~mm}$, for 7, 8; $\mathrm{e}-1 \mathrm{~mm}$, for $10-14$

along margin, inward thin-walled, with small, concave trigones, 25-33 $\mu \mathrm{m}$ in diameter. Leaves imbricate to contiguous, transversely inserted and incubously oriented, (2-)3-4-lobed, with sinus descending to 2/3-3/4 of leaf length, lobes narrowly triangular to lanceolate, unequal (dorsal lobe considerable larger, ventral sometimes reduced to branched cilia), densely ciliate throughout, 750-1000 $\times$ 850-1100 $\mu \mathrm{m}$. Underleaves appressed to the stem to narrowly spreading, divided by short sinus (to $1 / 4-1 / 3$ of underleaf length) into 3-4-several short, triangular lobes, densely ciliate throughout. Cells in the middle of leaf lamina 30-50 × 25-33 $\mu \mathrm{m}$, subisodiametric to oblong, trigones large, convex, sometimes confluent, median lamina mostly visible, intermediate thickenings sometimes present, cuticle smooth; oil bodies 20-35 per cell, smooth to granulate, spherical to elliptic, $2.0-2.5 \times 2.5-3.5 \mu \mathrm{m}$. Dioicous. Perianth terminal on main axis, tubular to ovate or rhomboidal in projection, exerted for $2 / 3$ of the length, 
smooth, 3-5-plicate in upper $1 / 4$ of the length, suddenly contracted to the mouth (near mouth pluriplicate), 2.0-3.0 $\times 1.0-1.2 \mathrm{~mm}$, with one subfloral innovation, densely ciliate at mouth, with cilia 3-6 cells long; female bracts 2-4-lobed, sinus descending to $1 / 2$ of the length; female bracteole ovate, with 2-3 short, triangular lobes, with many cilia (at least in lateral margins cilia numerous and branched). Seta 6-9 mm long, capsule ellipsoidal, ca. $1.2 \mathrm{~mm}$ long. Elaters bispiral, without homogenous ends, 130-200 × 5-6 $\mu \mathrm{m}$; spores brown, papillose, $27-35 \mu \mathrm{m}$ in diameter.

Comment. The comparison with weak forms of Ptilidium ciliare is done under the latter. In suboceanic areas of Sakhalin Province the confusion is also possible with P. californicum. Two species are easily differs even in the first glance due to pale to brown colored plants with densely ciliate leaf lobes of $P$. pulcherrimum versus bright brown to rusty-brown colored plants and leaf lobes entire to sparsely ciliate in $P$. californicum. In microscope examination the feature of underleaves are distinctive: the underleaves of P. pulcherrimum are only slightly subdivided, whereas underleaves of P. californicum are divided near to the base.

Ecology. Acidophilic mesophyte. Commonly in partly shaded habitats, rarely in open sites. The species possesses mainly epiphytic to epixylous nature, in boreal coniferous forests of the Russian Far East it is commonly the only liverwort epiphyte (the list of boreal coniferous epiphytes in the Russian Far East is exhaust additionally two taxa: Frullania bolanderi Austin and Radula complanata (L.) Dumort. - both are rarity in dark coniferous forests and absent in larch forests). The species continues the growth over tree trunks after they become fallen and decaying and Ptilidium pulcherrimum mats commonly mark the first stage of bryophyte succession on decaying wood in boreal zone. Aside coniferous forests the species is widely distributed in crooked forests (more commonly in those formed by Pinus pumila (Pall.) Regel rarer than those by Duschekia fruticosa (Rupr.) Pouzar.), relatively common in Betula ermanii and B. lanata (Regel) V.N. Vassil. forests (the transitional variants between true forests and krumholtz), everywhere as epiphyte or as epixylous. The species becomes sparser in hemiboreal forests and vanished in broadleaved deciduous cool temperate forests, although remains relatively common in oro-boreal belt of the mountains situated within temperate zone. Northward of subarctic the species hardly penetrate to tundra zone, where occurs over thin branches of dwarf shrubs, like Vaccinium and Salix. Aside woody substrates (died or alive) the species is rarely (in the extremes of the area) occurs in fine soil near tree trunks where form compact low patches. The species commonly form pure patches, rarer it associated with epiphytes and epixylous taxa like Neoorthocaulis attenuatus, Lophozia silvicoloides N. Kitag., L. longiflora (Nees) Schiffn., Lophocolea heterophylla (Schrad.) Dumort. In moist habitat (decaying wood near stream) once collected with Harpanthus flotovianus (Nees) Nees. In tree trunk bases occurs with Doninia plicata (Lindb.) Konstant. \& Vilnet. In northern extremes it was once collected on lying branch of Pinus pumila with arctic-alpine Tetralophozia setiformis for that the occurrence in decaying wood is highly uncharacteristic.
Distribution. Mainly boreal circumpolar taxon. In the Russian Far East it is distributed from the northern extremes of forested (including crooked forests) area (not known in Chukotka Autonomous District and Koryak Upland in the northern extremity of the Far East), hardly penetrating to tundra. In the southern flank of the area mostly occurs in upper altitudes (Fig. 3: B). The lowest altitude in southern extreme is that in Ussurijsky State Reserve at $43^{\circ} \mathrm{N}$, where the species was observed at $230 \mathrm{~m}$ a.s.l. Southward of our area penetrates to Kyushu (Yamada \& Iwatsuki 2006), sparse in Korean Peninsula (Choi 2013), North-East China and Chinese Shaanxii (Piippo 1990).

\section{Neotrichocoleaceae Inoue}

The Neotrichocoleaceae are small group includes only two monotypic genera: Neotrichocolea S. Hatt. and Trichocolepsis, the last circumscription of the family was published by Liu et al. (2008), who argued transfer of Trichocoleopsis from Lepidoleanaceae to Neotrichocoleaceae. Both genera are characterized by Korean-Japanese-Southeast Chinese orohemiboreal to oro-cool-temperate distribution. The family is characterized by freely pinnately branched stem (branching of Frullania type), transversely inserted and incubously oriented 3-6-lobed leaves with ventral lobe transformed into water sac, free lobes densely ciliate along margin, large bilobed underleaves and massive paraphyllose coelocaule. The only Trichocoleopsis reaches the Russian Far East being infrequent in the southern flank of Primorye Territory.

Trichocoleopsis S. Okamura, Bot. Mag. (Tokyo) 25(293): 159, 1911

The genus, admittedly, includes one species (Söderström et al. 2016). However, there is one more taxon described in the genus: Trichocoleopsis tsinlingensis P.C. Chen ex P.C. Wu, J.X. Luo \& M.Z. Wang - an illegitimate name (Art. 38.1(a); no description). It was treated as distinct species in Liu et al. (2008), who, curiously, despite using of molecular methods avoid to show whether two taxa are different or not. Moreover, the localities for T. tsinlingensis (l.c.) are the same with T. sacculata as mentioned in cited paper. The differentiation features includes only leaves with a few cilia in the former - the feature that likely may be environmentally induced.

Trichocoleopsis sacculata (Mitt.) S. Okamura, Bot. Mag. (Tokyo) 25(293):159, 1911 (三 Blepharozia sacculata Mitt., Trans. Linn. Soc. London, Bot. 3(3):200, 1891) (Fig. 2:H, 4:F, 10:1-8)

Description. Plants prostrate, rarely loosely ascending, greenish to purplish brownish and blackish purple in wellexposed sites, in herbarium commonly become yellowishbrownish, in loose pure mats or mixed with other bryophytes, $1.2-2.0 \mathrm{~mm}$ wide, $30-50 \mathrm{~mm}$ long (older portions decaying). Rhizoids virtually absent to common, separate or united into loose fascicles, originating from the stem near underleaf bases. Stem freely pinnately and bipinnately regularly branched, branches of Frullania type; stem cross section of well developed shoots transversely elliptic, $400 \times$ $560 \mu \mathrm{m}$, outer 1-2 layers of cells with somewhat thickened walls, with concave, moderate in size trigones, 18-30 $\mu \mathrm{m}$ in diameter, inward become thinner, in the middle part 

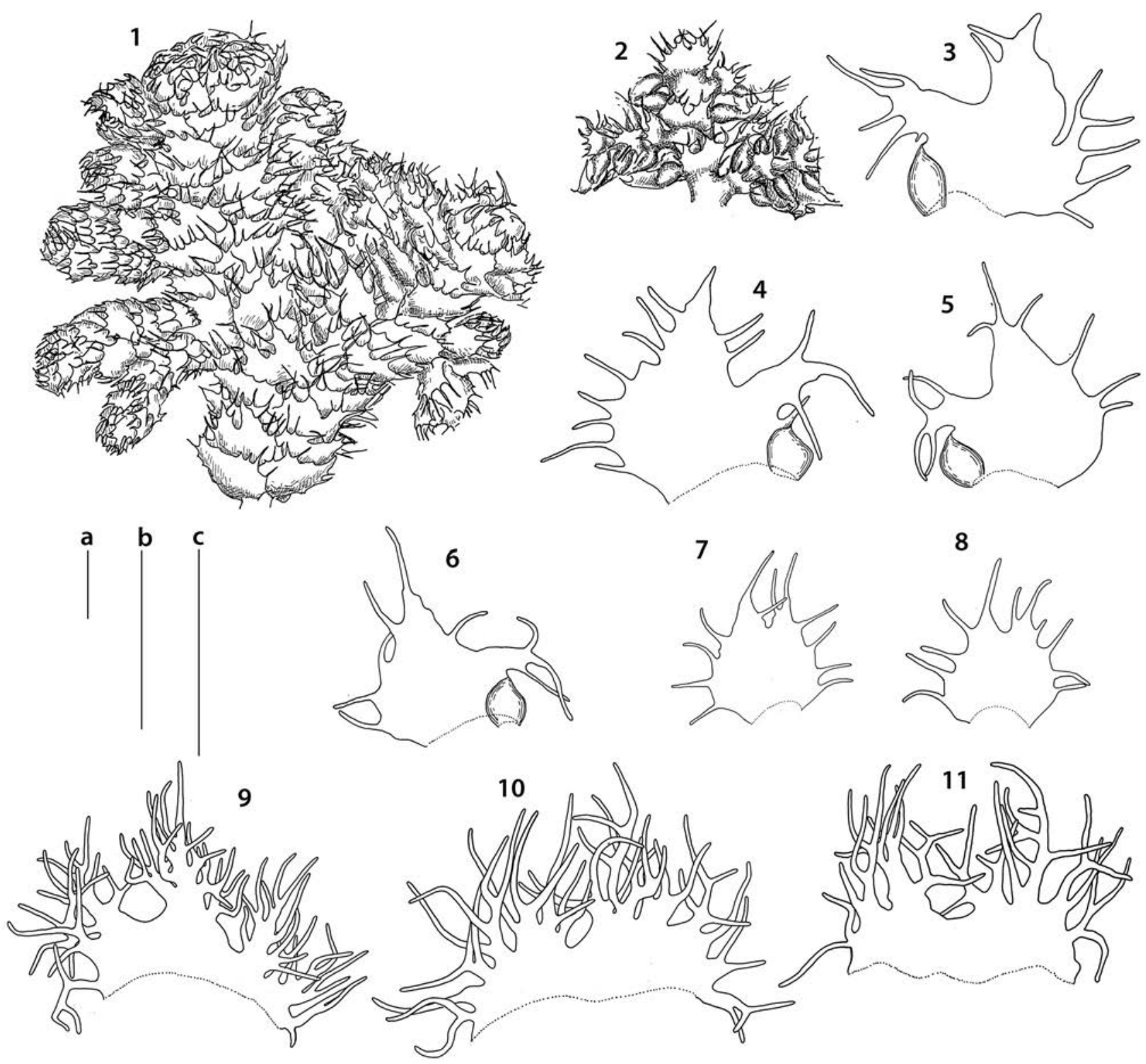

Figure 10 Trichocoleopsis sacculata (Mitt.) S. Okamura: 1 - habit, dorsal view; 2 - shoot ventral view, fragment; 3-6 - leaves; 7, 8 - underleaves. All from P-15-34-12 (VBGI). Trichocolea tomentella (Ehrh.) Dumort.: 9, 10 - leaves; 11 - underleaf. All from K-61-1-07 (VBGI). Scales: $\mathrm{a}-1 \mathrm{~mm}$, for 1,$2 ; \mathrm{b}-1 \mathrm{~mm}$, for 3-8; $\mathrm{c}-1 \mathrm{~mm}$, for $9-11$

very thin-walled, 25-40 $\mu \mathrm{m}$ in diameter, with concave trigones. Leaves imbricate to contiguous (in weak shoots), transversely inserted, incubously oriented, slightly convex, when flattened in the slide 1.0-1.5 × 1.2-1.7 mm, strongly unequally 3-4-lobed, with ventral lobe transformed into water sac, normally developed lobes strongly unequal, in 3-lobed leaves dorsal lobe larger, in 4-lobed the larger is the middle of normally developed (not transformed) lobes, sinus descending to $2 / 3$ of leaf length, margin strongly ciliate, pyxidate lobe $300-500 \times 250-350 \mu \mathrm{m}$, strongly involute. Underleaves regular, obliquely to erect spreading, obtrapezoidal, strongly vary in size (regardless of the size of corresponding leaf pair), 0.3-1.2 × 0.4-1.4 mm (excluding cilia!), deeply bifid to bisbifid by U-shaped sinus descending to $1 / 2-3 / 4$ of underleaf length (at minimum undivided portion may be 3 cells high only), densely ciliate along margin. Cells in the middle part of leaf lamina thin-walled, subisodiametric, $42-63 \times 37-50 \mu \mathrm{m}$, with moderate in size, concave trigones, intermediate thickenings $1-2$ per wall, rarely present, cuticle smooth; oil bodies $8-30$ per cell, finely granulate to nearly smooth, spherical, $3.0-3.5 \mathrm{~mm}$ in diameter to ellipsoidal, fusiform and irregularly oblong, 2.5-3.5 × 5.0-6.0 $\mu \mathrm{m}$; marginal cilia commonly 2 cells in the base and then with 1-4 paired cells and then 4-7-celled uniseriate end, cells of cilia 50-75 $\mu \mathrm{m}$ long.

Comment. Sometimes in moist cliffs of hemiboreal or cool-temperate communities of the southern flank of Primorye Territory this taxon may be, at the first glance, recognized as arcto-boreal Ptilidium ciliare. However, even if to put aside the unusual habitat for the latter taxon, Trichocoleopsis sacculata may be easily differentiated from the former due to presence of ventral lobe transformed into the water sac. Another feature of vegetative plants is deeply bilobed to bisbifid underleaves. 
Ecology. The ecology of the species is more or less similar across the distribution area and includes moist cliffs and boulders near (although aside of running water) and at the some distance of the streams, locally abundant near waterfalls in spray zone, rarer occupies decaying wood and roots of big trees above ground. The species is very sensitive to air moisture and occurs in narrow creeks or otherwise moistened (e.g. by wet air masses going from sea coast) habitats. It is hemiboreal to cool-temperate species, occurring across the area in mountains where restricted to the broadleaved deciduous communities and oro-hemiboreal mixed forests (in our area the forest dominant includes Picea koraiensis Nakai, Abies holophylla Maxim., A. nephrolepis (Trautv. ex Maxim.) Maxim., Taxus cuspidata Siebold \& Zucc., Fraxinus, Acer, Tilia and some other cool-temperate broadleaved forest taxa). Rarely going beyond of hemiboreal communities: once it was observed in oroboreal Abies nephrolepis-Betula lanata-Picea ajanensis forest. The species prefers partly shaded places, avoiding full shade and open sites (with the exception of sites near waterfalls where growing in sunny areas and acquires blackish purple pigmentation). The species commonly forms pure patches, sometimes occurring with Herbertus dicranus (Taylor ex Gottsche, Lindenb. \& Nees) Trevis., Tritomaria exsecta (Schmidel ex Schrad.) Schiffn. ex Loeske and Cheilolejeunea obtusifolia (Steph.) S. Hatt. in the canyons near streams and waterfalls.

Distribution. Mainly Korean-Japanese-East Chinese oro-hemiboreal to oro-cool-temperate taxon occurring westward to Sichuan, southward to Taiwan and northward to the southern flank of Sikhote-Alin Range in Primorye Territory (Fig. 3:C). In Japan the species is known from Hokkaido to Honshu (Yamada and Iwatsuki, 2006), relatively common across Korean Peninsula (Choi 2013), sparse in East China (Piippo 1990). Not known in Kuril Islands and Sakhalin and seems to be infrequent in Hokkaido. In our territory occurs in middle elevation of mountains rarely ascending to upper levels, although once observed at the elevation near $1100 \mathrm{~m}$ a.s.l.

\section{Trichocoleaceae Nakai}

Trichocoleaceae are most diverse in mountainous Gondwanalandic areas, tropical mountains, with a few taxa spreading to temperate zone of the Northern Hemisphere. The family includes (Söderström et al. 2016) three genera: Eotrichocolea R.M. Schust. (2 species), Leiomitra Lindb. (13 species) and Trichocolea (20 species), with only one species of the last genus present in southernmost flank of the Russian Far East. The diversity of Trichocolea in Japan becomes higher in southern portion of the country, where three species are known (Katagiri et al. 2013). The family is characterized by regularly 1-4-pinnately branched (if branches are present) plants, with braches of Frullania type, leaves transversely inserted and oriented, divided into 3-4 lobes those are subdivided into smaller secondary lobes then becoming to cilia, underleaves regular, 2-4-lobed, ciliate along margin, coelocaule present, perianth developed or not, calyptra lacking or present and polystratose capsule wall (Frey \& Stech 2009).
Trichocolea Dumort., Commentat. Bot. (Dumortier): 113, 1822

The genus is characterized by plants whitish when dry, numerous cilia in underleaves and leaves and absence of calyptra and perianth. The only one species is known in the Russian Far East

Trichocolea tomentella (Ehrh.) Dumort., Syll. Jungerm. Europ.: 67, 1831 (E Jungermannia tomentella Ehrh., Hannover. Mag. 21(18):277, 1783) (Fig. 2:G, 4:E, 10:9-11)

Description. Plants large, with soft leaves and rigid stem, pale yellowish to greenish and whitish, always whitish in the herbarium, varying in size from depauperate $5-7 \mathrm{~mm}$ wide to well-developed, 12-18 mm wide and 30-200 mm long (larger forms occurs southward of our area). Rhizoids virtually absent to sparse, in loose fascicles from the stem, originating near underleaf bases in basal part of shoot. Stem freely and commonly regularly bipinnately branched, lateral pinnae sometimes transform to main axis and give the start to the new shoots; cross section transversely elliptic, main axis 500-1000 $\mu \mathrm{m}$, outer cells small and thick-walled, $10-22 \mu \mathrm{m}$ in diameter, trigones small, concave, inward cell walls become thinner and cells larger, in the middle part very thin-walled, $25-50 \mu \mathrm{m}$ in diameter, with small, concave trigones. Leaves on the main axis transversely inserted and nearly transversely oriented, well developed 700-1200 × $800-1500 \mu \mathrm{m}$, basically with 3-4 lobes, each of that may be additionally subdivided into secondary lobes, sinus U-shaped, undivided lamina portion $3-5$ cells high, margin of primary lobes and lobes of the second order ciliate, with cilia commonly additionally branched, branched cilia and lacinae originating al the lobe margin, then sometimes go at right angle with the lobe surface to outer side and after 2-3 cells curved in the same plane with leaf lamina that make impression of cilia originating over leaf lamina, not at the margins only. Underleaves regular, convex, obliquely to erect spreading, with 2-4 lobes, sometimes divided into smaller secondary lobes and with branched cilia along margin, cilia oriented similarly with those in the leaves, the undivided portion 2-3 cells high. Cells in leaf lamina middle oblong, $25-45 \times 15-30 \mu \mathrm{m}$, thin-walled, with small to moderate in size, concave trigones; cells in the lobes $50-85 \times 17-25 \mu \mathrm{m}$, thin-walled or walls slightly thickened; cells in cilia $70-100 \mu \mathrm{m}$ long, thin-walled to somewhat thickened, with small trigones, cuticle smooth throughout to distinctly striolate; oil bodies in cilia cells $2-4$ per cell, irregularly oblong, very finely papillose.

Comment. Among Russian taxa this is the very distinctive taxon due to numerous and repeatedly branched cilia that the separate leaf is difficult to see with naked eye, the stem and branches appears as covered by fuzz. The possible confusion at the generic level may occurs with Neotrichocolea bissetii (Mitt.) S.Hatt. from the same family (may be found in East-Manchurian mountains spurs in the Russian Far East), sterile plant of that however differs in common development of reddish to brownish (to almost purple) secondary pigmentation and especially in well-developed leaf lamina completely covered by cilia originating from outer surface. Among taxa of the genus, the species is somewhat resembling mainly Japanese Trichocolea japonica T. Katag. that 
may be found in southernmost extreme of insular Russian Far East. The latter differs from T. tomentella in strongly papillose-verrucose cuticle of cilia and epidermal cells of capsule with linear to semiannular inner thickenings, versus nearly smooth to striolate cilia cuticle and epidermal cells of capsule without inner thickenings (Katagiri et al. 2013).

Ecology. Acido- to neutrophilic meso-hygrophyte growing on various substrates including decaying wood, humus in moist slopes in shady forests, fine soil and boulders along streams and cliffs in shady and moist places in evergreen to deciduous and hemiboreal coniferous and mixed forests. Within the Russian Far East the species is restricted to the moist hemiboreal forests, where occurs on decaying wood and in humus in steep slopes. Highly sensitive to air moisture (due to the low drought tolerance) and does not occurs in open sites. The species commonly form pure patches, although once was observed together with Harpanthus flotovianus in moss mats along stream.

Distribution. Broadly circum-temperate taxon occurring in Europe from southern Norway to Portugal, reported from North Africa (Tunisia), in European Russia sparsely occurs in temperate communities in its western part, eastward to Vologda Province, then as rarity in south Siberia (Altai Mts.), widely distributed in East Asia, Malesia and penetrates to Papua, occurs in the east of North America southward of subarctic (Katagiri et al. 2013). Within the Russian Far East occurs in southernmost extreme of Kurils (Shikotan and Kunashir Islands) thus in the area under strong moisturizing effect of Pacific Ocean in low altitudes (below $150 \mathrm{~m}$ a.s.l.) (Fig. 3:C). In Japan occurs at considerable higher localities, although remains observable in low altitudes, rare in Korean Peninsula (Choi 2013), sparse in China (Piippo 1990).

\section{ACKNOWLEDGEMENTS}

Author is sincerely grateful to Mr. M. Bakalin for line drawings preparation for the present account. The work was partially supported by Russian Foundation for Basic Researches (grant no. 17-04-00018).

\section{LITERATURE CITED}

Bakalin, V.A. 2010. Distribution of bryophytes in the Russian Far East. Part. I. Hepatics. Vladivostok, Izd-vo DVFU, 175 pp.

Bakalin, V.A. 2015. Tardoki-Yani Range (North Sikhote-Alin, Pacific Russia) - the largest southern refugium of arcticalpine liverwort flora in East Asia. Arctoa 24:314-326.

Bakalin, V.A. \& K.G. Klimova 2019. Porellaceae (Hepaticae) in the Russian Far East. Botanica Pacifica 8(1):1-27.

Chang, K.-C. \& C. Gao 1984. Plantae novae hepaticarum sinarum. Bulletin of Botanical Research. Harbin 4(3):83-99.

Choi, S.S. 2013. Taxonomy of the liverworts and hornworts in Korea. PhD thesis. Chonbuk National University, Jeonju, 606 pp. (in Korean).
Frey, W. \& M. Stech 2009. Marchantiophyta, Bryophyta, Anthocerotophyta. In: Syllabus of Plant Families (W. Frey, ed.), pp. 1-257, Borntraeger, Stuttgart.

Gao, C. \& K.-C. Chang 1981. Flora hepaticarum Chinae borealiorientalis. Science Press, Beijing, 220 pp. (in Chinese).

Guerke, W.R. 1978. A monograph of the genus Jubula Dumortier. J. Cramer, Vaduz, 118 pp.

Iwatsuki, Z. 1972. Distribution of bryophytes common to Japan and the United States. In: Floristics and paleofloristics of Asia and Eastern North America (A. Graham, ed.), pp. 107-137, Elsevier.

Katagiri, T., A. Sadamitsu, H. Miyauchi, H. Tsubota \& H. Deguchi 2013. Taxonomic studies of the Trichocoleaceae in Southeast Asia. III. The genus Trichocolea Dumort. Hattoria 4: 1-42.

Kreier, H.-P., K. Feldberg, F. Mahr, A. Bombosch, A.R. Schmidt, R.-L. Zhu, M. von Konrat, B. Shaw, A.J. Shaw \& J. Heinrichs 2010. Phylogeny of the leafy liverwort Ptilidium: Cryptic speciation and shared haplotypes between the Northern and Southern Hemispheres. Molecular Phylogenetics and Evolution 57(3):1260-1267.

Larraín, J., B. Carter, B. Shaw, J. Hentschel, L.S. Strozier, T. Furuki, J. Heinrichs, B. Crandall-Stotler, J. Engel \& M. von Konrat 2015. The resurrection of Neobattoria Kamim. (Jubulaceae, Marchantiophyta): a six decade systematic conflict resolved through a molecular perspective. PhytoKeys 50:101-122.

Leonardi, L. 2002. Ptilidiaceae Klinggräff. In: Flora of North America, vol. 29, electronic version, http://www. mobot.org/plantscience/bfna/v3/PtilPtilidium.htm, last accessed 1 August 2018.

Liu, Y., Y. Jia, W. Wang, Z.-D. Chen, E.C. Davis \& Y.-L. Qiu 2008. Phylogenetic relationships of two endemic genera from East Asia: Trichocoleopsis and Neotrichocolea (Hepaticae). Annals of the Missouri Botanical Garden 95(3): 459-470.

Piippo, S. 1990. Annotated catalogue of Chinese Hepaticae and Anthocerotae. Journal of the Hattori Botanical Laboratory 68:1-192.

Söderström, L., A. Hagborg, M. von Konrat, S. BartholomewBegan, D. Bell, L. Briscoe, E. Brown, D.C. Cargill, D.P. Costa, B.J. Crandall-Stotler, E.D. Cooper, G. Dauphin, J.J. Engel, K. Feldberg, D. Glenny, S.R. Gradstein, X. He, J. Heinrichs, J. Hentschel, A.L. Ilkiu-Borges, T. Katagiri, N.A. Konstantinova, J. Larran, D.G. Long, M. Nebel, T. Pôcs, F. Felisa Puche, E. Reiner-Drehwald, M.A.M. Renner, A. Sass-Gyarmati, A. Schâfer-Verwimp, J.G.S. Moragues, R.E. Stotler, P. Sukkharak, B.M. Thiers, J. Uribe, J. Vâna, J.C. Villarreal, M. Wigginton, L. Zhang \& R.-L. Zhu 2016. World checklist of hornworts and liverworts. PhytoKeys 59:1-828.

Yamada, K. \& Z. Iwatsuki 2006 Catalog of the hepatics of Japan. Journal of the Hattori Botanical Laboratory 99: 1-106. 


\section{Appendix: SPECIMENS EXAMINED}

All cited materials are from the Russian Far East; only one specimen per locality is cited; all materials are in VBGI, the collector name is given in full with the exception of V. Bakalin who is abbreviated to VB

\section{Jubula japonica}

RUSSIA: PRIMORSKY TERRITORY Livadijsky Range 400 m a.s.l., 4308'03"N 13247'56"E, P-20-22-12 VB 27.VI.2012. Neohattoria herzogii

RUSSIA: KHABAROVSK TERR. De Castri 106 m a.s.l., 5137'55"N 14054'05"E, s.n. Roenko E. 06.VIII.2011; SAKHALIN

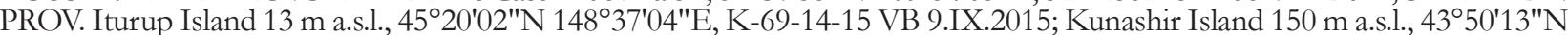

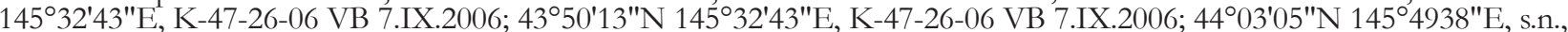
Eryomenko N.A. 2.XI.1999.

\section{Nipponolejeunea pilifera}

RUSSIA: SAKHALIN PROV. Iturup Island 100 m a.s.l., 45²0'02"N 148³7'04"E, K-71-6-15 VB 11.IX.2015;

\section{Nipponolejeunea subalpina}

RUSSIA: SAKHALIN PROV. Zhdanko Mt. 300 m a.s.l., 4305'28"N 142³1'30"E, S-48-7-16 VB 1.X.2016; Due Bav 100 m a.s.l., 5050'13"N 14206'29"E, S-59-24-09 VB 6.IX.2009; Kamyshovyj Range 365 m a.s.l., 5052'56"N 142²1'44"E, S-57-4209 VB 5.IX.2009; Zhdanko Mt. $350 \mathrm{~m}$ a.s.l., 48 03'00"N 142 31'44"E, S-26-11-09 VB 20.VIII.2009; Iturup Island $10 \mathrm{~m}$ a.s.l.,

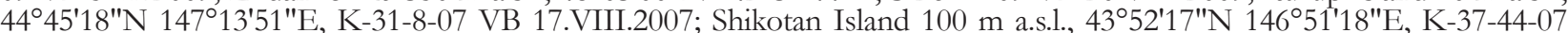

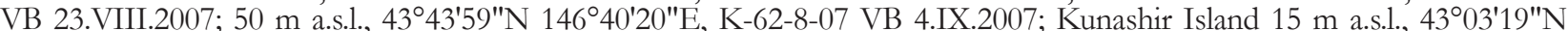

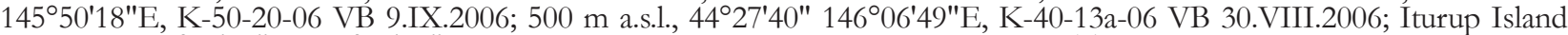

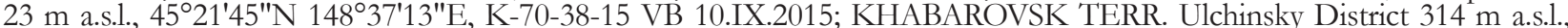
5138'59"N 14055'26"E, s.n. Roenko E. 5.VIII.2011; PRIMORSKY TERR. Livadijsky Range 1300 m a.s.l., 4304'15"N $132^{\circ} 41^{\prime} 37^{\prime \prime E}$ P-40-9-10 VB 6.IX.2010;

\section{Ptilidium californicum}

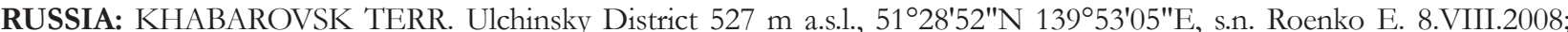
SAKHALIN PROV. Schmidt Peninsula $177 \mathrm{~m}$ a.s.l., 5402'48"N 14249'15"E, S-46-4-09 VB 1.IX.2009; $400 \mathrm{~m}$ a.s.l., $54^{\circ} 04^{\prime} 10^{\prime \prime N} 142^{\circ} 49^{\prime} 26^{\prime E} \mathrm{E}, \mathrm{S}-48-25-09$ VB 1.IX.2009; East-Sakhalin Mountains s.d. $\mathrm{m}$ a.s.l., 50 $14^{\prime} \mathrm{N} 143^{\circ} 19^{\prime} \mathrm{E}$, Cherdantseva

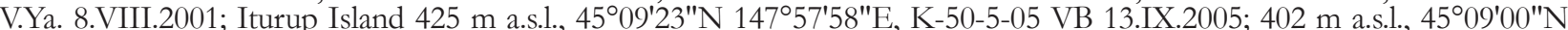
$147^{\circ} 57^{\prime} 50 " \mathrm{E}, \mathrm{K}-48-3-05^{\mathrm{VB}}$ 13.IX.2005.

\section{Ptilidium ciliare}

RUSSIA: AMURSKAYA PROV. Tukuringra Range $522 \mathrm{~m}$ a.s.1., $54.2742^{\circ} \mathrm{N} 126,8275^{\circ} \mathrm{E}$ Br-12-092 Dudov S.V. 25.VII.2012; EVREISKAYA AUTONOMOUS REGION Dichun River s.d. $m$ a.s.l., 48 $34^{\prime} 13^{\prime \prime} \mathrm{N} 130^{\circ} 50^{\prime} 58^{\prime \prime}$ E, s.n. Selivanova E. 23.VIII.1926; KAMCHATKA TERR. Tigil River $450 \mathrm{~m}$ a.s.l., 56³9'12"N 15901'16"E, K-132-33-04 VB 11.IX.2004; Tolbachik Volkano $1030 \mathrm{~m}$ a.s.l., 55 $49^{\prime} \mathrm{N} 160^{\circ} 20^{\prime} \mathrm{E}$ s.n. Czernyadjeva I.V. 21.VIII.2006; MAGADAN PROV. Annachag

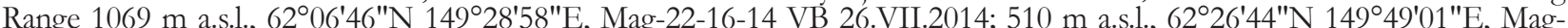
28-6-14 VB 3.VIII.2014; 1270 m a.s.l., 62045'46"N 149²0'53"E, Mag-24-9-14 VB 29.VII.2014; Kamennyy Range 880 m

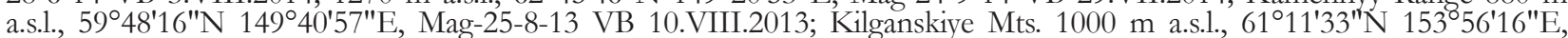

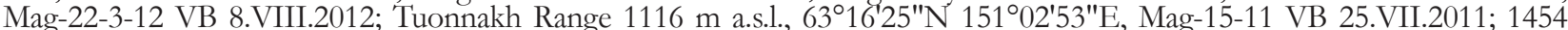

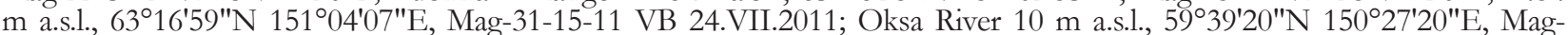
25-4-11 VB 17.VII.2011; Olskove Basalt Plateau 1150 m a.s.l., 60³8'38"N 151 26'22"E, Mag-30-33-14 VB 6.VIII.2014; 840

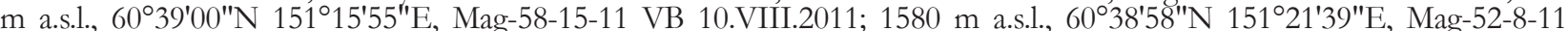
VB 8.VIII.2011; Zamkovaya Mt. $580 \mathrm{~m}$ a.s.l., 63⒉'16"N 152 37'53"E, Mag-44-50-11 VB 31.VII.2011; Kulu s.d. m a.s.l.,

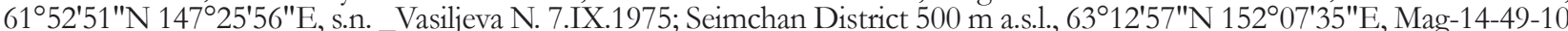
VB 13.VI.2010; PRIMORSKY TERR. Partizansky District $1660 \mathrm{~m}$ a.s.l., 43⒉ $6^{\prime} 48^{\prime \prime} \mathrm{N} 133^{\circ} 39^{\prime 2} 21^{\prime \prime E}, \mathrm{P}-35-21-14$ VB 12.IX.2014;

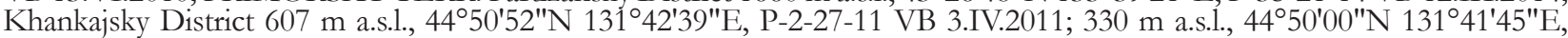
P-1-1-11 VB 2.IV.2011; KHABAROVSK TERR. Tardoki-Yani $1927 \mathrm{~m}$ a.s.l., 48 53'00"N 13802'31"E, Kh-34-2-13 VB 22.VIII.2013; Botchi River s.d. $\mathrm{m}$ a.s.l., $48.296^{\circ} \mathrm{N} 139.577^{\circ} \mathrm{E}$ Kh-72-08-08 Chibiryak T.O. 22.VIII.2008; Ulchinsky District 288

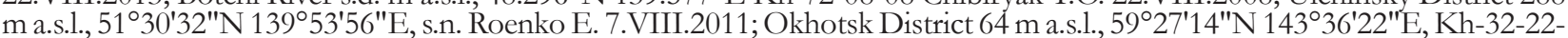
08 VB 23.VII.2008; Bolshoj Shantar Island s.d. $\mathrm{m}$ a.s.l., 550' $\mathrm{N} 137^{\circ} 55^{\prime} \mathrm{E}$ s.n. Ivchenko T.I. 11.VIII.2016; Badzhal Range 1640

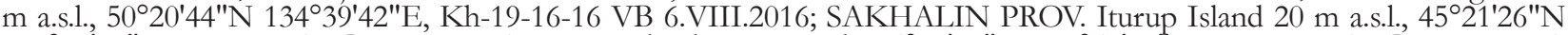

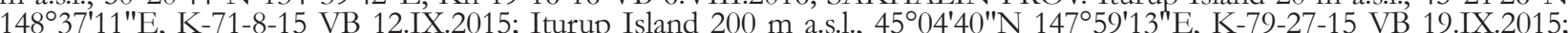

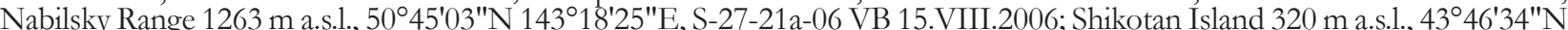
14644'19"E, K-42-11-07 VB 25.VIII.2007; Yuzhno-Sakhalinsk Municipality 937 m a.s.l., 4654'18"N 142 55'58"E, S-38-13-05 VB 3.IX.2005; Bolshoi Garomaj 9 m a.s.l., 52³1'39"N 14307'46"E, S-31-12-09 VB 24.VIII.2009; Balagan Mts. 1335 m a.s.l., $50^{\circ} 37^{\prime} 59^{\prime \prime N} 143^{\circ} 21^{\prime} 44^{\prime \prime} \mathrm{E}, \mathrm{S}-19-9-17$ VB 9.VII.2017.

\section{Ptilidium pulcherrimum}

RUSSIA: AMURSKAYA PROV. Zejsky District $702 \mathrm{~m}$ a.s.l., 53.7777 ${ }^{\circ} \mathrm{N} 127.379^{\circ} \mathrm{E} 2016 \_B r \_0029$ Dudov S.V. 21.VIII.2016; KAMCHATKA TERR. Kozyrevsky District $78 \mathrm{~m}$ a.s.l., 56 03'37"N 159 54'32"E, K-99-7a-03 VB 18.VIII.2003; Kamchatsky Peninsula 326 m a.s.l., 56 07'15"N 16248'54"E, K-7-4-06 VB 7.VII.2006; Ganalsky Range $900 \mathrm{~m}$ a.s.l., 5356'16"N 15801'29"E, K-56-3-15 VB 11.VIII.2015; KHABAROVSK TERR. Okhotsk District 132 m a.s.l., 59 26'00"N 143⒉'57"E, Kh-20-1-08 VB 19.VII.2008; Botchi River 30 m a.s.l., 4800'39"N 139 26'04"E, s.n. Chibiryak T.O. 20.VIII.2008; Ulchinsky District 242

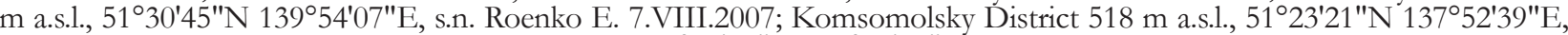

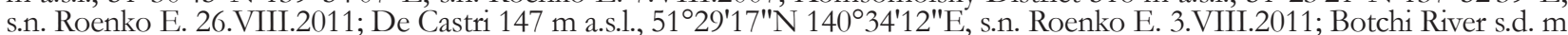
a.s.l., $48.302^{\circ} \mathrm{N} 139.577^{\circ} \mathrm{E}$ s.n. Chibiryak T.O. 20.VIII.2008; Solnechnyy District $980 \mathrm{~m}$ a.s.l., 5042'53"N 136 23'49"E, Kh-514-07 VB 29.V.2007; Okhotsk District 321 m a.s.l., 59 25'08"N $143^{\circ} 29^{\prime} 36^{\prime \prime E}$, Kh-36-10-08 VB 25.VII.2008; Gobilli River 418 $\mathrm{m}$ a.s.l., $49^{\circ} 16^{\prime} 00^{\prime \prime N} 138^{\circ} 21^{\prime} 35^{\prime \prime E}$, Kh-71-11-09 VB 21.IX.2009; Badzhal Range $600 \mathrm{~m}$ a.s.l., 50¹5'43"N 134'41'48"E, Kh-161-16 VB 2.VIII.2016; Tardoki-Yani 1300 m a.s.l., 4851'39"N 13804'02"E, s.n. Malashkina E.V. 28.VIII.2012; MAGADAN PROV. Magadan Municipality 350 m a.s.l., 59 31'19"N 150'49'23"E, Mag-61-20-11 VB 11.VIII.2011; Olskoye Basalt Plateau $840 \mathrm{~m}$ a.s.l., $60^{\circ} 39^{\prime} 00^{\prime \prime} \mathrm{N} 151^{\circ} 15^{\prime} 55^{\prime \prime E}$, Mag-58-1-11 VB 10.VIII.2011; Tuonnakh Range $652 \mathrm{~m}$ a.s.l., $63^{\circ} 19^{\prime} 30^{\prime \prime} \mathrm{N} 151^{\circ} 25^{\prime} 42^{\prime \prime} \mathrm{E}$, Mag-41-38-11 VB 28.VII.2011; Kamennyy Range $511 \mathrm{~m}$ a.s.l., 59 49'06"N 14940'35"E, Mag-22-2-13 VB 9.VIII.2013;

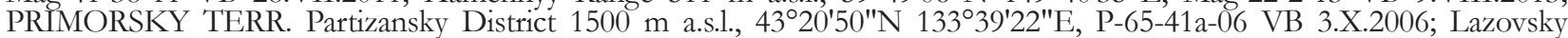

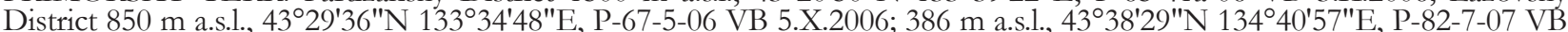
21.IX.2007; Livadijsky Range 1200 m a.s.l., 4304'15"N 132 41'37"E, P-74-13-05 VB 10.X.2005; Shkotovsky District 229 m

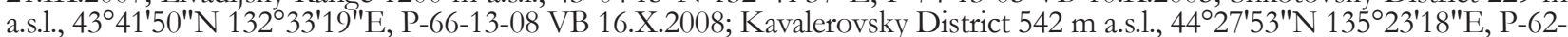
15-11 VB 15.IX.2011; Chuguvevsky District $1000 \mathrm{~m}$ a.s.l., 4344'19"N 134²5'33"E, P-75-1-07 VB 17.VII.2007; SAKHALIN

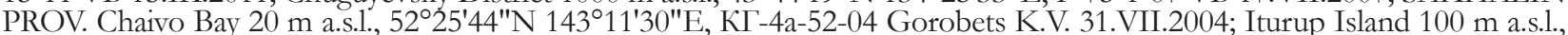

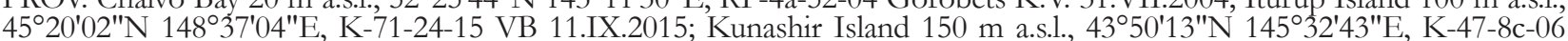


VB 7.IX.2006; Belaya River 68 m a.s.l., 47015'16"N 14248'47"E, S-25-9a-06 VB 12.VIII.2006; Schmidt Peninsula 61 m a.s.l., $54^{\circ} 01^{\prime} 01^{\prime \prime N ~ 142} 56^{\prime} 34^{\prime \prime E}$, S-39-8-09 VB 29.VIII.2009; Korsakovsky District 85 m a.s.l., 46²6'58"N 143²3'08"E, S-65-5-09 VB 16.IX.2009; Shikotan Island 100 m a.s.l., 4352'17"N 14651'18"E, K-37-21-07 VB 23.VIII.2007.

Trichocolea tomentella

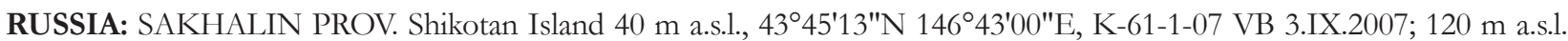

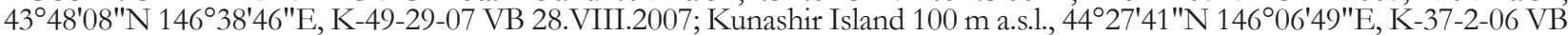
28.VIII.2006; $150 \mathrm{~m}$ a.s.l., 4350'13"N 14532'43"E, K-47-9-06 VB 7.IX.2007.

Trichocoleopsis sacculata

RUSSIA: PRIMORSKY TERR. Livadijsky Range $550 \mathrm{~m}$ a.s.l., 4307'10"N 13247'31"E, P-15-34-12 VB 25.VI.2012; $444 \mathrm{~m}$

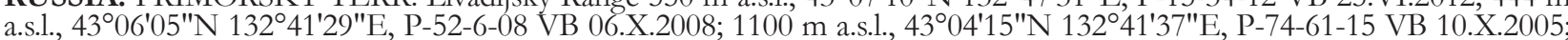

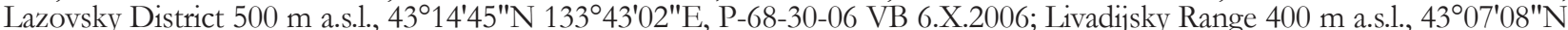
132 45'45"E, P-40-25-12 VB 18.IX.2012; Khasansky District 500 m a.s.l., 4305'38"N 131 $30^{\prime} 35^{\prime \prime E}$, P-3-41-07 VB $18 . V .2007$. 